\title{
Chromosome Banding in Amphibia. XXXI. The Neotropical Anuran Families Centrolenidae and Allophrynidae
}

\author{
Michael Schmid ${ }^{a}$ Claus Steinlein ${ }^{a}$ Wolfgang Feichtinger ${ }^{a}$ James P. Bogart $^{b}$

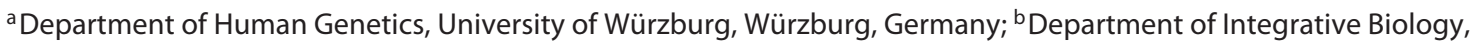 \\ University of Guelph, Guelph, Ont., Canada
}

\section{Key Words}

Allophrynidae $\cdot$ Anura $\cdot$ Centrolenidae $\cdot$ Chromosome evolution · Sex chromosomes

\begin{abstract}
The mitotic chromosomes of 11 species from the anuran families Centrolenidae and Allophrynidae were analyzed by means of conventional staining, banding techniques, and in situ hybridization. The amount, location, and fluorochrome affinities of constitutive heterochromatin, the number and positions of nucleolus organizer regions, and the patterns of telomeric DNA sequences were determined for most of the species. The karyotypes were found to be highly conserved with a low diploid chromosome number of $2 n=20$ and morphologically similar chromosomes. The sister group relationship between the Centrolenidae and Allophrynidae (unranked taxon Allocentroleniae) is clearly corroborated by the cytogenetic data. The existence of heteromorphic XYơ/XXo sex chromosomes in an initial stage of morphological differentiation was confirmed in Vitreorana antisthenesi. The genome sizes of 4 centrolenid species were determined using flow cytometry. For completeness and for comparative purposes, all previously published cytogenetic data on centrolenids are included.

(c) 2014 S. Karger AG, Basel
\end{abstract}

During the pre-banding era of cytogenetics, very few studies included tropical glass frogs (family Centrolenidae). These were confined to 4 species (Cochranella granulosa, Espadarana prosoblepon, Hyalinobatrachium fleischmanni, and Sachatamia albomaculata) and were carried out using classical squash techniques and uniformly stained chromosomes in the diakinesis stage of male meiosis (table 1). The early studies did demonstrate the existence of a strikingly low chromosome number ( $\mathrm{n}=10,2 \mathrm{n}=20$ ) in centrolenids. A single further study on somatic tissues of Vitreorana eurygnatha revealed that all 10 chromosomes have a biarmed (metacentric or submetacentric) morphology (table 1). No cytogenetic studies have previously been published for the sister taxon of the Centrolenidae, the family Allophrynidae.

Banding analyses were only applied to 2 males and 2 females of the Venezuelan centrolenid species Vitreorana antisthenesi which revealed XY $\sigma^{\top} / \mathrm{XX}$ ? sex chromosomes in an initial stage of morphological differentiation and unusually large amounts of brightly labeled, AT-rich constitutive heterochromatin in the centromeric and pericentromeric regions of all autosomes and in the X chromosome [Schmid et al., 1989].

A new phylogenetic taxonomy, based on molecular, morphological, anatomical, behavioral, and biogeo-

\section{KARGER}

E-Mail karger@karger.com

www.karger.com/cgr
(C) 2014 S. Karger AG, Basel

$1424-8581 / 14 / 1424-0268 \$ 39.50 / 0$ 
graphical data, has been proposed for the Centrolenidae [Guayasamin et al., 2008, 2009]. These studies recognized the evolutionary proximity of the families Centrolenidae and Allophrynidae and combined both into the unranked taxon Allocentroleniae. The family Centrolenidae includes the subfamilies Centroleninae and Hyalinobatrachinae and comprises 11 genera: Centrolene (34 species), Chimerella (1 species), Cochranella (24 species), Espadarana (3 species), Nymphargus (30 species), Rulyrana (8 species), Sachatamia (3 species), Teratohyla (4 species), Vitreorana (8 species), Celsiella (2 species), and Hyalinobatrachium (27 species). The genus Ikakogi (1 species) was described by Guayasamin et al. [2009] and, because it could not be assigned with confidence to either subfamily, was included as incertae sedis in the Centrolenidae. The family Allophrynidae contains the single genus Allophryne ( 3 species). Two of these species were only recently described [Castroviejo-Fisher et al., 2012; Caramaschi et al., 2013].

Glass frogs are distributed throughout the Neotropics, from Mexico to Bolivia, including the Caribbean island of Tobago, with highest species diversity in the northern Andes (Colombia and Ecuador), and with a large hiatus in the lower Amazon basin. An isolated group of species occurs in southeastern Brazil and northeastern Argentina [Duellman, 1977; Cannatella and Duellman, 1982; Guayasamin et al., 2009]. They live mainly in cloud and rain forests and are nocturnal and arboreal. Females deposit egg clutches on the underside of leaves, or on rocks, above running water. After hatching, the tadpoles fall into the water to complete their development. Some species, however, are also known to occasionally breed in ponds. As a further diagnostic character, the skin and flesh of the ventral surfaces are partially or completely transparent owing to the scarcity of pigments. This allows the viscera to be observed through the abdominal wall [Duellman and Burrowes, 1989; Ruiz-Carranza and Lynch, 1991; Duellman and Trueb, 1994; Cisneros-Heredia and McDiarmid, 2007; Kubicki, 2007; Guayasamin et al., 2009]. As pointed out by Guayasamin et al. [2009], glass frogs represent one of the most interesting neotropical anuran groups because of their morphological and ecological characteristics, as well as their phylogenetic and biogeographic complexity.

The 3 described species of the family Allophrynidae occur from the Guiana region of South America (Venezuela, Guyana, Surinam, French Guiana, northern central Brazil) to central Brazil, northeastern Amazonian Peru and the Atlantic rain forest of eastern Brazil [Langone and Segalla, 1997; Caldwell and Hoogmoed, 1998; Guayasamin et al., 2009; Castroviejo-Fisher et al., 2012; Caramaschi et al., 2013]. Allophrynids live in forests and flooded forests. They are arboreal or semi-arboreal and nocturnal.

The present study examines the mitotic chromosomes of 10 species in the family Centrolenidae and 1 species in the family Allophrynidae and provides results for several banding techniques and fluorescence in situ hybridization (FISH) experiments that were applied to the chromosomes of 8 species of Centrolenidae. The amount, chromosomal location and composition of the constitutive heterochromatin, the number and location of nucleolus organizer regions (NORs) as well as the patterns of repetitive telomeric DNA sequences were determined. The existence of heteromorphic XY $\sigma^{7} / \mathrm{XX}$ ? sex chromosomes in an initial stage of morphological differentiation was confirmed for $V$. antisthenesi. The genome sizes of 4 centrolenid species were determined using DNA flow cytometry. For completeness and for comparative purposes, all previously published cytogenetic data on centrolenids are included and re-evaluated.

\section{Materials and Methods}

\section{Animals}

Individuals representing 11 species belonging to the genera $\mathrm{Co}$ chranella (C. granulosa), Espadarana (E. prosoblepon), Hyalinobatrachium (H. colymbiphyllum, $H$. duranti, $H$. fleischmanni, $H$. fragile, $H$. orientale, $H$. valerioi), Vitreorana (V. antisthenesi, V. eurygnatha) (family Centrolenidae), and Allophryne (A. ruthveni) (family Allophrynidae) were collected during various expeditions to Costa Rica, Venezuela, Brazil and the island of Tobago (table 1). The chromosomes of the Venezuelan species were prepared in a temporary cytogenetic laboratory in the field station Estación Biológica de Rancho Grande located in the Henri Pittier National Park, Aragua State. The Costa Rican specimens were prepared in a temporary cytogenetic laboratory in the Departamento de Biología, University of Costa Rica, San José. Tissue obtained for chromosomes was transferred to $1.8-\mathrm{ml}$ plastic tubes (Nunc), stored at $4^{\circ} \mathrm{C}$ or $-20^{\circ} \mathrm{C}$ and transported to the laboratory in Würzburg (Germany), either packed in dry ice or at room temperature. Frogs collected in Tobago were carried alive to Würzburg where their chromosomes were prepared. Chromosomes of the specimens sampled in Brazil were prepared in the field. All procedures with the living animals strictly conformed to the guidelines established by the Animal Care Committees of the respective countries.

\section{Chromosome Preparations}

Mitotic chromosomes were prepared directly from the bone marrow, intestines or the cornea of the eye after in vivo colchicine treatment. Meiotic chromosomes were obtained from testes. Detailed techniques used for squash preparations (cornea) and cell suspensions (bone marrow, intestine, testes), as well as the hypotonic treatment and fixation of the cells have been previously described [Schmid et al., 2010]. 
Table 1. Species from the families Centrolenidae and Allophrynidae cytogenetically examined in the present study and in previous reports

\begin{tabular}{|c|c|c|c|c|c|}
\hline Species $^{\mathrm{a}}$ & Country & $\begin{array}{l}\text { Speci- } \\
\text { mens }^{b}\end{array}$ & Locality ${ }^{c}$ & $\begin{array}{l}\text { Geographical } \\
\text { coordinates }^{\mathrm{d}}\end{array}$ & $2 \mathrm{n} / \mathrm{FN}^{\mathrm{e}}$ \\
\hline \multicolumn{6}{|c|}{$\begin{array}{l}\text { Family Centrolenidae, subfamily Centroleninae } \\
\text { Cochranella granulosa* }\end{array}$} \\
\hline Present study & Costa Rica & $\begin{array}{l}10^{x} \\
10^{7}\end{array}$ & $\begin{array}{l}\text { Carara National Park, Puntarenas Province } \\
\text { Río Sucio, Braulio Carrillo National Park, Limón Province }\end{array}$ & $\begin{array}{l}09^{\circ} 44^{\prime} \mathrm{N} / 84^{\circ} 37^{\prime} \mathrm{W} \\
10^{\circ} 09^{\prime} \mathrm{N} / 83^{\circ} 58^{\prime} \mathrm{W}\end{array}$ & $\begin{array}{l}20 / 40 \\
20 / 40\end{array}$ \\
\hline Duellman, 1967 & Nicaragua & $20^{*}$ & Finca Tepeyac, 10.5 km N, 9 km E Matagalpa, 960 m, Matagalpa Department & $11^{\circ} 58^{\prime} \mathrm{N} / 86^{\circ} 05^{\prime} \mathrm{W}$ & $20^{\ddagger} / \mathrm{n} . \mathrm{i}$. \\
\hline \multicolumn{6}{|l|}{ Espadarana prosoblepon* } \\
\hline $\begin{array}{l}\text { Present study } \\
\text { León, } 1970 \text { \& pers. commun. } \\
\text { Duellman, } 1967\end{array}$ & $\begin{array}{l}\text { Costa Rica } \\
\text { Costa Rica } \\
\text { Panama }\end{array}$ & $\begin{array}{l}70^{x} 19 \\
\text { not } \\
10^{x}\end{array}$ & $\begin{array}{l}\text { Alto de la Palma, Limón Province } \\
\text { Campus of the University, San José } \\
\text { Finca Ojo de Agua, SE slope of Cerro la Pelota, } 1440 \text { m, Chiriqui Province }\end{array}$ & $\begin{array}{l}10^{\circ} 02^{\prime} \mathrm{N} / 83^{\circ} 59^{\prime} \mathrm{W} \\
09^{\circ} 56^{\prime} \mathrm{N} / 84^{\circ} 02^{\prime} \mathrm{W} \\
08^{\circ} 54^{\prime} \mathrm{N} / 82^{\circ} 42^{\prime} \mathrm{W}\end{array}$ & $\begin{array}{l}20 / 40 \\
20 \ddagger / n . i . \\
20^{\ddagger} / \text { n.i. }\end{array}$ \\
\hline \multicolumn{6}{|l|}{ Sachatamia albomaculata } \\
\hline \multicolumn{6}{|l|}{ Vitreorana antisthenesi } \\
\hline Present study & Venezuela & $190^{x} 4$ 운 & $\begin{array}{l}\text { Henri Pittier National Park, small mountain stream at km } 29 \text { on road to } \\
\text { Ocumare de la Costa, } 650 \mathrm{~m} \text {, Aragua State }\end{array}$ & $10^{\circ} 24^{\prime} \mathrm{N} / 67^{\circ} 45^{\prime} \mathrm{W}$ & $20 / 40$ \\
\hline Schmid et al., 1989 & Venezuela & $2 \sigma^{\top} 29$ & $\begin{array}{l}\text { Henri Pittier National Park, small mountain stream at } \mathrm{km} 29 \text { on road to } \\
\text { Ocumare de la Costa, } 650 \mathrm{~m} \text {, Aragua State }\end{array}$ & $10^{\circ} 24^{\prime} \mathrm{N} / 67^{\circ} 45^{\prime} \mathrm{W}$ & $20 / 40^{\dagger}$ \\
\hline \multicolumn{6}{|l|}{ Vitreorana eurygnatha } \\
\hline Present study; Bogart, 1973 & Brazil & $\begin{array}{l}10^{\pi} \\
1 \mathrm{u}\end{array}$ & $\begin{array}{l}\text { Tijuca forest at Bom Retiro, Guanabara, Rio de Janeiro State } \\
\text { Teresópolis, Serra dos Órgãos National Park, Rio de Janeiro State }\end{array}$ & $\begin{array}{l}22^{\circ} 53^{\prime} \mathrm{S} / 43^{\circ} 13^{\prime} \mathrm{W} \\
22^{\circ} 22^{\prime} \mathrm{S} / 42^{\circ} 45^{\prime} \mathrm{W}\end{array}$ & $\begin{array}{l}20 / 40 \\
20 / 40\end{array}$ \\
\hline
\end{tabular}

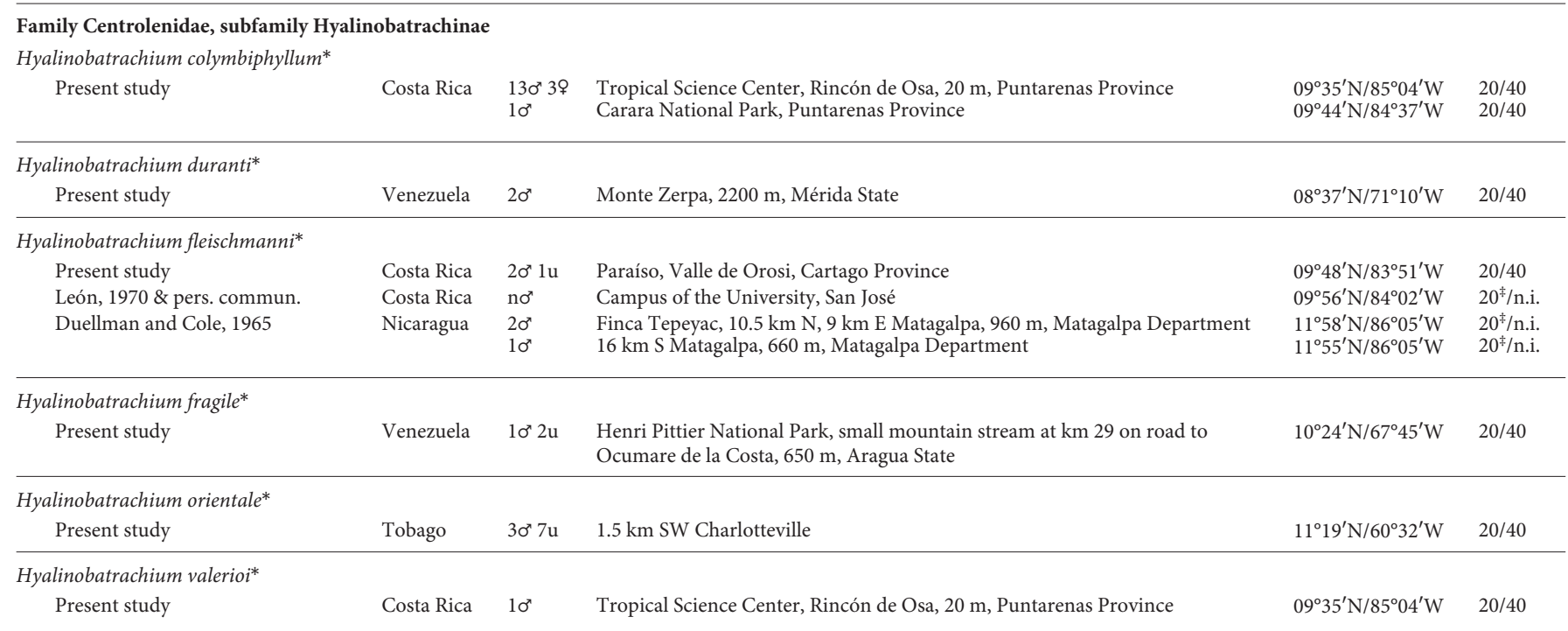

Family Allophrynidae

Allophryne ruthveni*

Present study Brazil $\quad 60^{\circ} \quad$ near A-Ukre on the Rio Xingu, Pará State $\quad 20 / 40$

${ }^{a}$ Mitotic chromosomes of the species labeled with * are published here for the first time. The identification of Hyalinobatrachium duranti is not confirmed. The specimens of Vitreorana eurygnatha published by Bogart [1973] are included in the present study.

${ }^{\mathrm{b}} \mathrm{n}=$ Unknown number of male specimens; $\mathrm{u}=$ sex unknown.

${ }^{c}$ Localities of specimens were obtained from collector's field books, personal communication with the collectors, as well as information from museums where the cytogenetically examined voucher specimens are deposited. $\mathrm{m}=$ Meters above sea level.

${ }^{\mathrm{d}}$ Geographic coordinates were determined either directly in the field using Global Positioning Systems (GPS), or by consulting the 'Directory of Cities and Towns in World' database (http://www.fallingrain.com/world/), Google Earth, or are based on extrapolations from geographical maps.

${ }^{\mathrm{e}}$ n.i. = Not indicated. ${ }^{\ddagger}$ Diploid chromosome number inferred from chromosome counts in meiosis. ${ }^{\dagger}$ The fundamental number is not explicitly mentioned in the text of the corresponding publication but inferred from the chromosome illustration or text. 
Banding Analyses and FISH

Conventional chromosome staining, C-banding, staining with quinacrine mustard, DAPI (4',6-diamidino-2-phenylindole) or Hoechst 33258, fluorescence counterstaining with distamycin A/ mithramycin or actinomycin D/DAPI, and labeling of the NORs with $\mathrm{AgNO}_{3}$ were performed according to the methods in Schmid et al. [2010].

For the detection of the canonical $\left(5^{\prime} \text {-TTAGGG- } 3^{\prime}\right)_{n}$ telomeric repeats, a fluorescein-conjugated peptide nucleic acid (PNA) probe (Telomere PNA FISH kit/FITC, K5325; Dako Cytomation, Denmark) was used. Detailed procedures for in situ hybridization and signal detection are provided by the manufacturer.

Microscopic analyses were conducted using Zeiss photomicroscopes III, Zeiss fluorescence microscopes and Zeiss Axiophot microscopes equipped with incident HBO 50W mercury lamp illumination. The various filter combinations necessary for the analyses of metaphases stained with the different fluorochromes or for FISH were described by Schmid et al. [2010].

\section{DNA Flow Cytometry}

Blood samples were obtained by cardiac puncture and were immediately fixed in $70 \%$ ethanol. The fixed samples were transferred to 1.8 -ml plastic (Nunc) tubes and stored at $-20^{\circ} \mathrm{C}$. Thawed samples were centrifuged ( $800 \mathrm{rpm}, 10 \mathrm{~min}$ ) in a laboratory centrifuge, and the erythrocyte pellets were resuspended and incubated in $1 \mathrm{ml}$ pepsin solution $(0.5 \%$ in $0.1 \mathrm{M} \mathrm{HCl})$ at room temperature for $15 \mathrm{~min}$. After the addition of $5 \mathrm{ml}$ staining solution $(2 \mu \mathrm{g} / \mathrm{ml}$ DAPI in $0.2 \mathrm{M}$ sodium citrate), the erythrocyte suspensions were kept at room temperature for $3 \mathrm{~h}$ [Otto, 1994], and were then mixed with chicken erythrocytes. Flow cytometric analyses were carried out with an epi-illumination flow system (Partec Cell Analyzer CAII) at $365 \mathrm{~nm}$ (filter combination KG1/BG38/UG1 for excitation, TK420 as dichromatic mirror, and GG435 as the barrier filter). Several measurements were performed for each sample. The nuclear DNA content of the frogs was calibrated against the known genome size of chicken erythrocytes (2.33 pg DNA/nucleus).

\section{Results}

\section{Karyotypes}

All 10 centrolenid species analyzed in the present and previous studies, as well as Allophryne ruthveni have a conserved diploid chromosome number of $2 \mathrm{n}=20$ (table 1; figs. 1, 3a). Only male meiotic metaphases, in the stage of diakinesis, were analyzed for S. albomaculata [Duellman, 1967], and no more information on this karyotype is available. The other 10 species possess a fundamental number of $\mathrm{FN}=40$, with 20 biarmed chromosomes (fig. 1). Only a few mitotic metaphases of moderate quality could be obtained for $H$. valerioi, but these were sufficient to evaluate the chromosome morphology (fig. 3). Centrolenid chromosomes have a metacentric or submetacentric morphology (figs. 1, 3a). In most species, chromosome pairs 1-8 decrease slightly in their lengths, with only small size differences between adjacent pairs, whereas pairs 9 and 10 are distinctly smaller (fig. 1a-h). $H$. orientale is an exception because all 10 chromosome pairs decrease gradually in size (fig. 1i). In the karyotype of $A$. ruthveni, chromosome pairs 1-6 decrease gradually in size and are larger than the pairs 7-9, which share similar lengths. Pair 10 is distinctly smaller (fig. 1j). Distinct nucleolar constrictions are visible in the short arms of chromosomes 2 in $V$. antisthenesi and $H$. colymbiphyllum, as well as in chromosomes 1 in $H$. duranti and $A$. ruthveni (fig. 1c, e, f, j). A comparison between the different karyotypes suggests that centrolenid and allophrynid species have maintained a considerable degree of chromosome homeology.

In all 19 male specimens of $V$. antisthenesi examined, chromosome pair 6 was found to be heteromorphic after conventional staining (fig. 1c) and banding analysis (see below). Although both of these chromosomes have about the same length $(6.0-6.5 \mu \mathrm{m})$, one of them (Y chromosome) is distinctly more submetacentric than the other (X chromosome) in all examined metaphases. The arm ratio (long arm length:short arm length) is approximately 3.5 for the Y chromosome and 2.3 for the X chromosome. In all female individuals, chromosome pair 6 is homomorphic, and both homologs have the same arm ratio of 2.3 as does the $\mathrm{X}$ chromosome in the male karyotype. The fact that the heteromorphism of chromosome pair 6 in $V$. antisthenesi is restricted to males demonstrates that the XYo $\sigma^{\prime}$ XXo type of chromosomal sex determination operates in this species. This confirms preliminary results obtained by Schmid et al. [1989] from $V$. antisthenesi that were collected in the same population as the specimens sampled for the present study. There is no evidence for the existence of heteromorphic sex chromosomes in the karyotypes of the other species.

\section{Constitutive Heterochromatin}

The patterns of constitutive heterochromatin in centrolenid chromosomes are like those in the karyotypes of most other anurans [Schmid, 1978a, b; Schmid et al., 1987, 2010, 2012]. C-bands are preferentially located in centromeric and pericentromeric regions of the chro-

Fig. 1. Conventionally stained karyotypes of the examined species of Centrolenidae and Allophrynidae. The XY sex chromosomes of $V$. antisthenesi are framed (c). Material was obtained from bone marrow except for $V$. eurygnatha (d) and A. ruthveni (j) whose chromosomes were obtained from squashed corneal epithelial cells and photographed unstained using phase-contrast optics.

(For figure see next page.)

Cytogenet Genome Res 2014;142:268-285 271
Chromosome Banding in Amphibia.

XXXI. Centrolenidae and Allophrynidae

DOI: 10.1159/000362216 


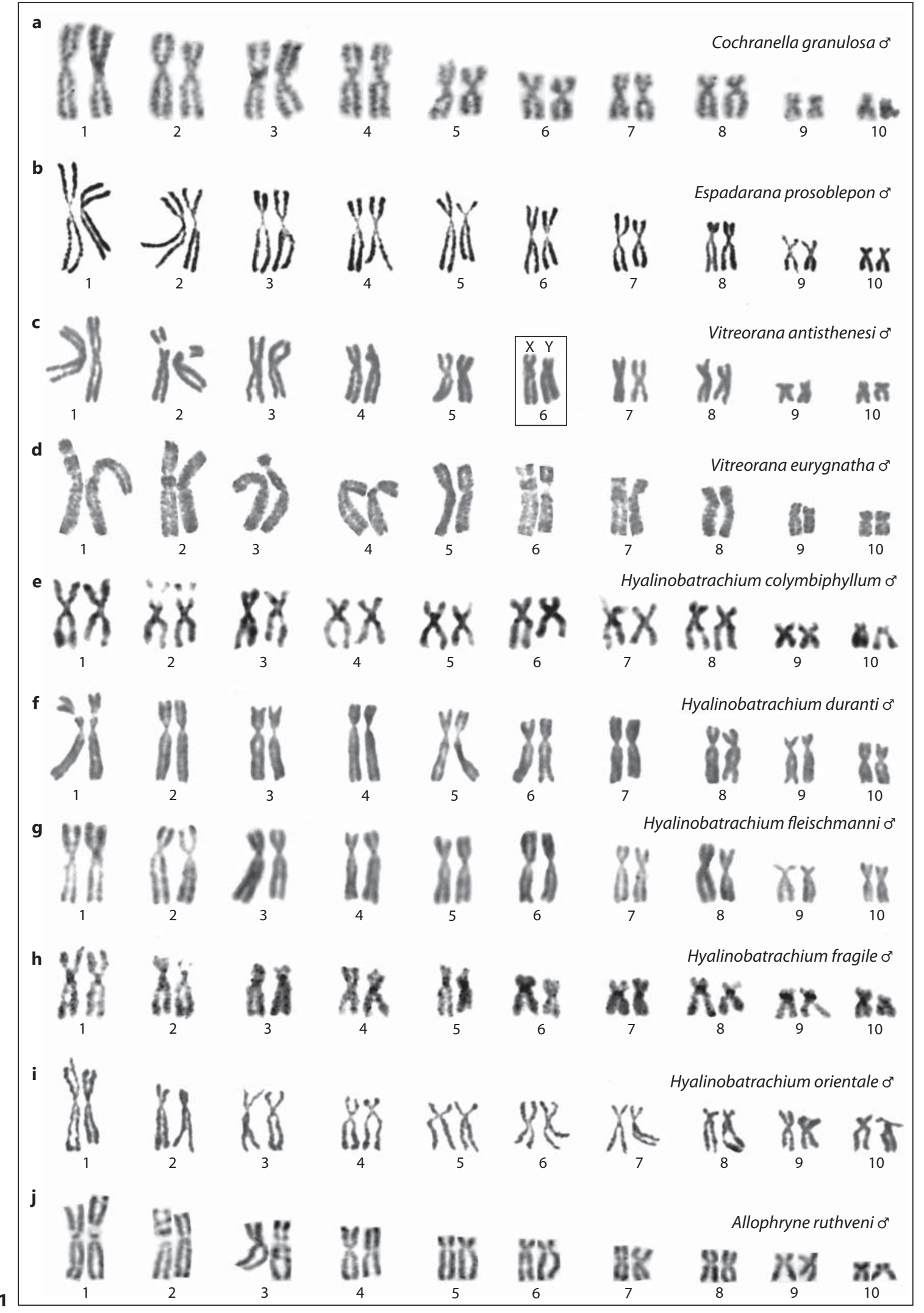




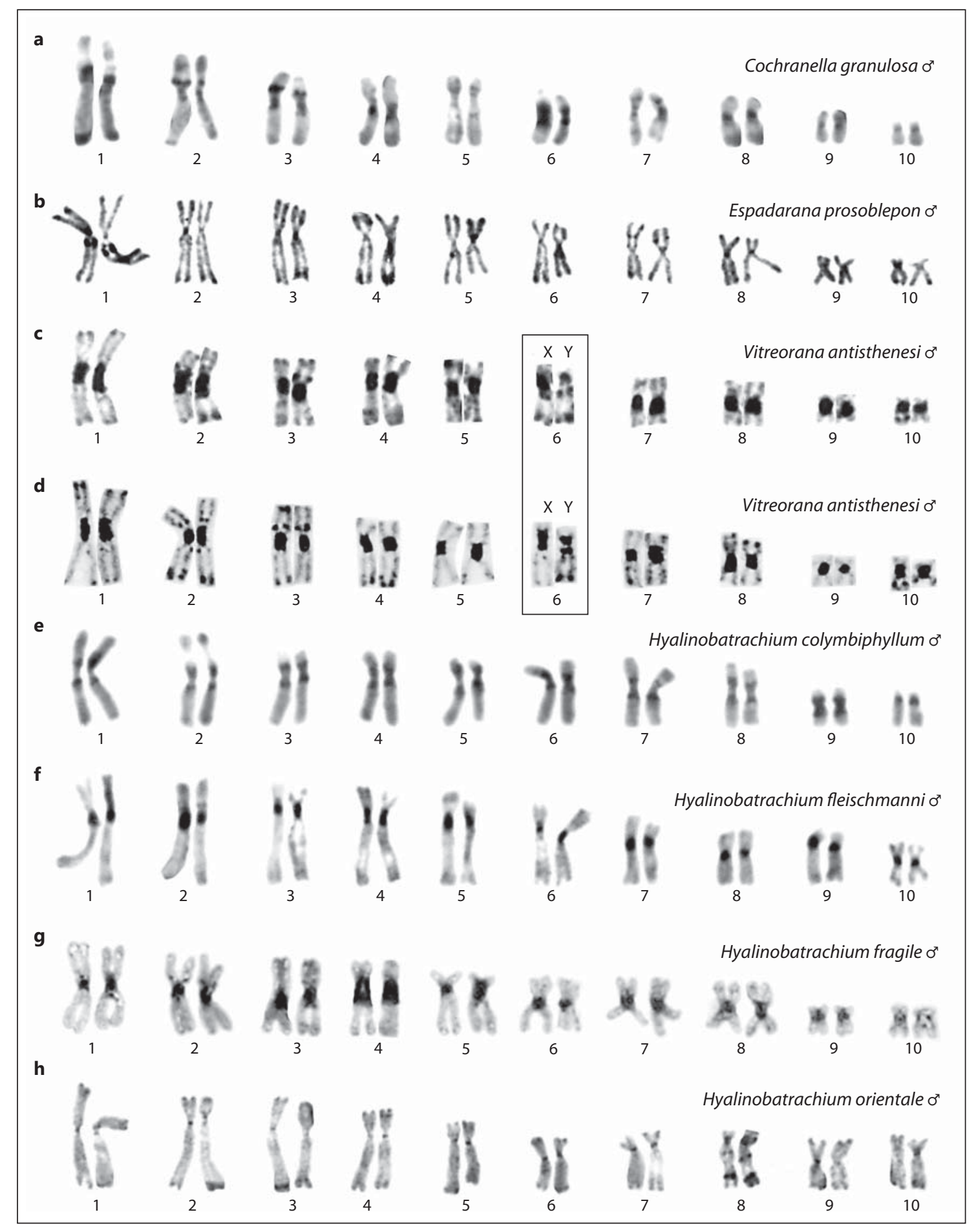

Fig. 2. C-banded karyotypes of the centrolenid species analyzed. Note the large amounts of centromeric and paracentromeric heterochromatin in $V$. antisthenesi $(\mathbf{c}, \mathbf{d}), H$. fleischmanni $(\mathbf{f})$ and $H$. fragile $(\mathbf{g})$. The heteromorphic $\mathrm{XY}$ sex chromosomes of $V$. antisthenesi are framed $(\mathbf{c}, \mathbf{d})$. Material obtained from bone marrow. 
Fig. 3. a-c Metaphase chromosomes of Hyalinobatrachium valerioi after conventional staining (a), C-banding (b) and Agstaining (c). The 4 NORs are marked by arrowheads. d Ag-stained interphase nuclei of $H$. valerioi cells showing the presence of 4 labeled nucleoli. Material obtained from bone marrow.

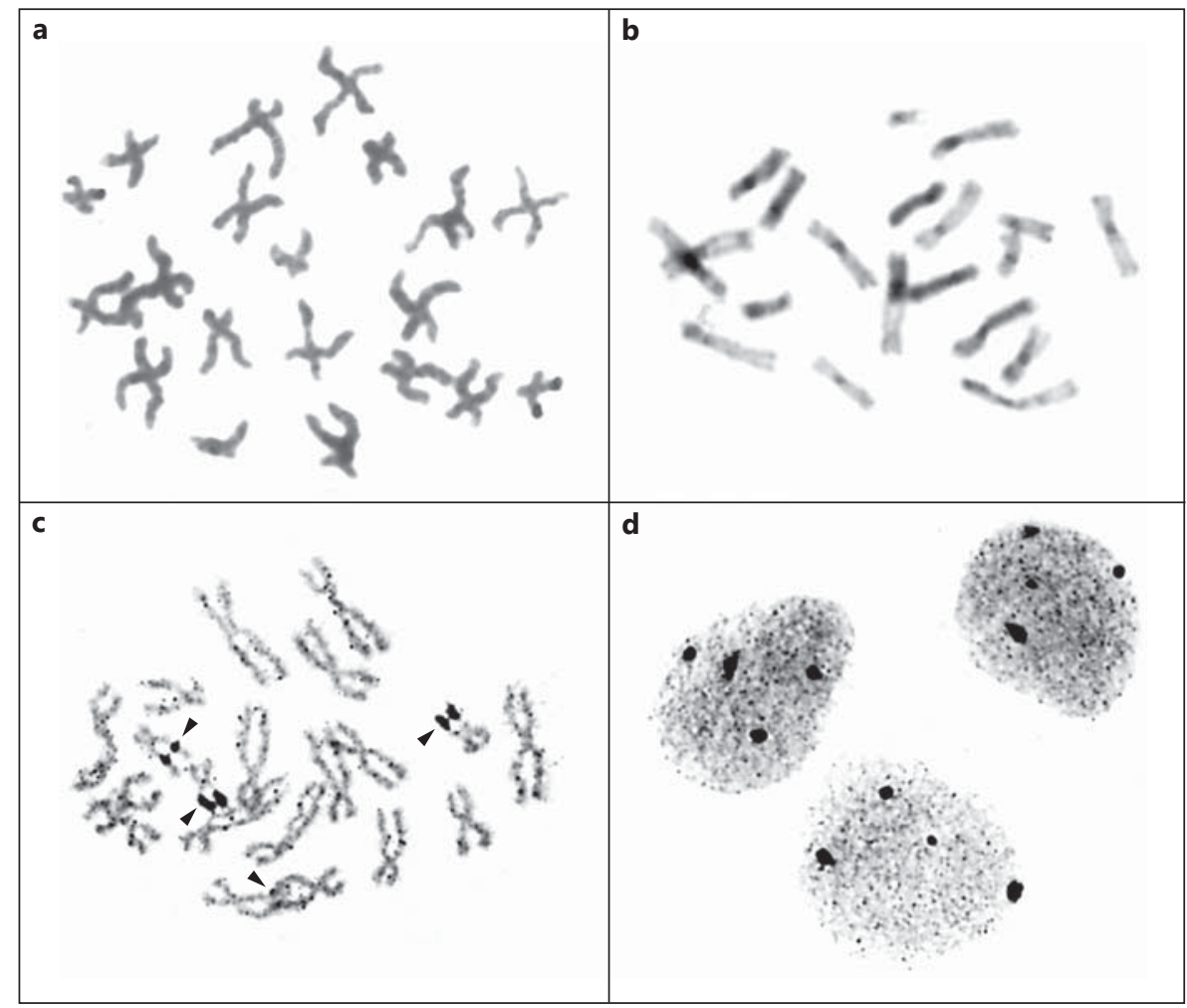

mosomes (figs. 2, 3b). The small chromosomes usually contain just as much constitutive heterochromatin as do the largest chromosomes. Very large centromeric and pericentromeric C-bands are located in the chromosomes of $V$. antisthenesi, $H$. fleischmanni and $H$. fragile (figs. 2c, d, f, g, 5d). The smallest amounts of centromeric and pericentromeric heterochromatin are found in the karyotypes of E. prosoblepon and H. orientale (fig. $2 \mathrm{~b}$, h). Intercalary C-bands are positioned in the chromosome 1 long arm and chromosome 7 short arm of E. prosoblepon (fig. 2b), in the chromosomes 2 and 3 short arms and the chromosomes 1, 2 and 10 long arms of $V$. antisthenesi (fig. $2 \mathrm{c}, \mathrm{d}$ ), and in the chromosome 8 long arm of $H$. orientale (fig. 2h). With the exception of $V$. antisthenesi (fig. $2 \mathrm{c}, \mathrm{d}$ ), the amount of telomeric and NOR-associated heterochromatin in the centrolenid karyotypes is rather small when compared with other anuran species. It should be emphasized that the XY sex chromosomes of $V$. antisthenesi contain the same amounts of centromeric and pericentromeric heterochromatin (figs. 2c, d, 5d). However, in many of the Cbanded metaphases, the constitutive heterochromatin in the $\mathrm{X}$ appears more darkly stained than in the $\mathrm{Y}$ (not shown). Furthermore, the telomeric heterochromatin in the Y long arm seems to be distinctly larger than in the $\mathrm{X}$ long arm (fig. 2d).

As expected from the results obtained in the chromosomes of other anuran families [for reviews, see Schmid et al., 2010, 2012], staining with the fluorochrome quinacrine mustard shows that the large euchromatic segments of centrolenid chromosomes fluoresce with a uniform and moderate intensity (figs. 4, 5a-c). All chromosome regions fluorescing either distinctly brighter or distinctly weaker than the euchromatin consist of constitutive heterochromatin or NORs (as confirmed, respectively, by Cbanding and Ag-staining).

The quinacrine-stained karyotype of $V$. antisthenesi is remarkable because of the large amounts of quinacrinepositive $\left(\mathrm{Q}^{+}\right)$heterochromatin in the centromeric and pericentromeric regions of all autosomes and in the $\mathrm{X}$ chromosome (figs. 4c, 5a-c). The Y chromosome contains the least amount of $\mathrm{Q}^{+}$heterochromatin in the karyotype. Only 2 very small $\mathrm{Q}^{+}$bands, one in the centromeric region and the other in the long arm telomeric region can be recognized in the Y. Neither in the X chromosome, nor in the autosomes is $\mathrm{Q}^{+}$heterochromatin located in the telomeric regions (figs. $4 \mathrm{c}, 5 \mathrm{a}-\mathrm{c}$ ). In metaphases prestained with quinacrine and subsequently C- 


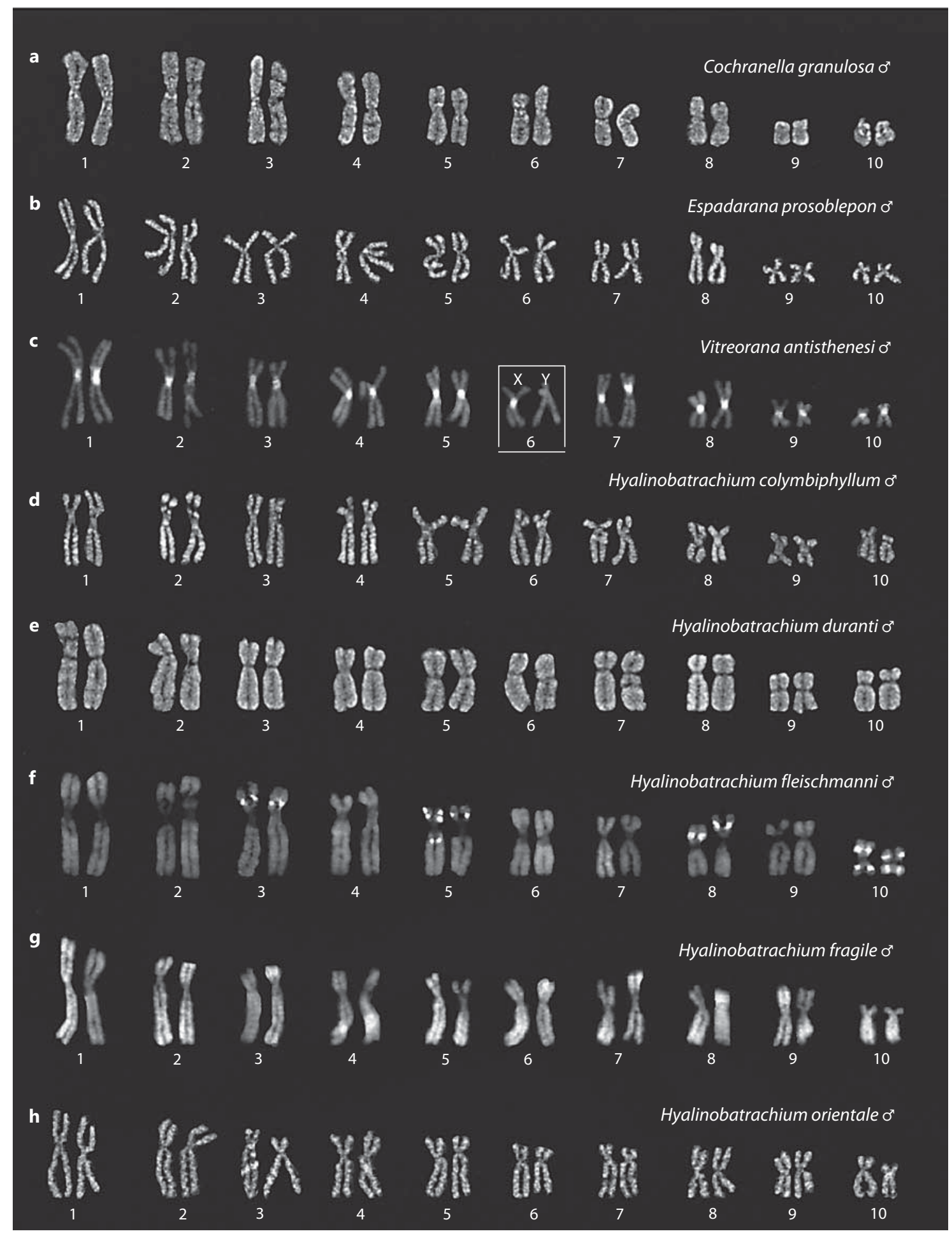

Fig. 4. Karyotypes of the centrolenid species after quinacrine mustard staining. Note the quinacrine-bright centromeric and pericentromeric heterochromatin in all autosomes and in the X chromosome of V. antisthenesi (c), and the quinacrine-bright interstitial heterochromatic bands in chromosome pair 10 of C. granulosa (a), as well as in the chromosome pairs 3, 5, 8, and 10 of H. fleischmanni (f). The heteromorphic XY sex chromosomes of $V$. antisthenesi are framed (c). Material obtained from bone marrow.

Chromosome Banding in Amphibia. XXXI. Centrolenidae and Allophrynidae
Cytogenet Genome Res 2014;142:268-285 DOI: $10.1159 / 000362216$ 


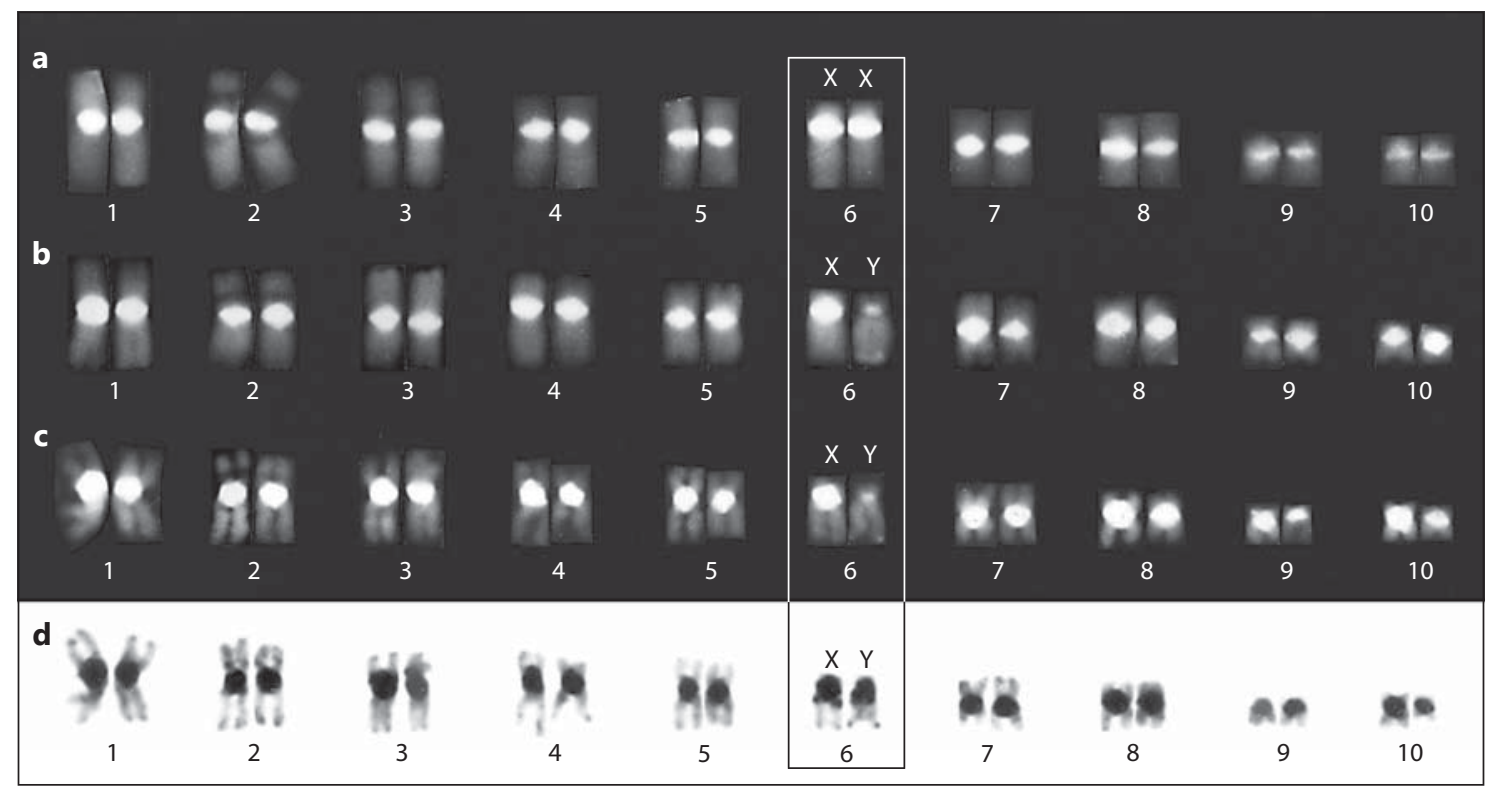

Fig. 5. Karyotypes of female (a) and male (b-d) Vitreorana antisthenesi after quinacrine mustard staining $(\mathbf{a}-\mathbf{c})$ and C-banding (d). The quinacrine-stained chromosomes in c were subsequently C-banded in $\mathbf{d}$. The sex chromosomes are framed. Note the large amounts of quinacrine-bright centromeric and pericentromeric heterochromatin in all autosomes and in the $\mathrm{X}$ chromosome. In the Y chromosome, all the C-band-positive pericentromeric heterochromatin is quinacrine-negative, whereas the small region of centromeric heterochromatin and the long arm telomeric heterochromatin is quinacrine-positive. Material obtained from bone marrow. banded, the very bright $\mathrm{Q}^{+}$bands in the autosomes and in the $\mathrm{X}$ chromosome colocalize with the dark C-bands. In the $\mathrm{Y}$ chromosome, however, the centromeric and pericentromeric C-bands are distinctly larger than the $\mathrm{Q}^{+}$ bands (fig. 5c, d). A close comparison of Q- and C-banded metaphases revealed that only a small band at the $\mathrm{Y}$ centromeric region is $\mathrm{Q}^{+}$, whereas all of the pericentromeric heterochromatin is not specifically labeled by quinacrine mustard. The comparison of Q-banded Y chromosomes of the 19 males examined showed that there exists a slight size variation of their $\mathrm{Q}^{+}$centromeric heterochromatin. Finally, the small telomeric $\mathrm{Q}^{+}$band located in the $\mathrm{Y}$ long arm (figs. $4 \mathrm{c}, 5 \mathrm{a}-\mathrm{c}$ ) is labeled by C-bands (figs. $2 \mathrm{~d}$, $5 d)$.

In C. granulosa, $\mathrm{Q}^{+}$heterochromatin is present in both arms of chromosomes 10 (fig. 4a). In the karyotype of $H$. fleischmanni, distinct $\mathrm{Q}^{+}$heterochromatin is located in the short arms of chromosomes 3, 5, 8 and 10 as well as in the long arms of chromosomes 5 and 10 (fig. 4f). In one of the males, the $\mathrm{Q}^{+}$-band in the chromosome 5 long arm is absent in one of the homologs (fig. $4 \mathrm{f}$ ), whereas in the other male and an unsexed individual it is present in both homologs (not shown). Other brightly fluorescing Q- bands were not detected in the karyotypes of the studied centrolenids.

Direct staining of centrolenid chromosomes with the fluorochromes DAPI and Hoechst 33258 or counterstaining with actinomycin D/DAPI yield the same banding patterns as induced by quinacrine. After counterstaining with distamycin A/DAPI, the heterochromatic regions fluoresce slightly more brightly than the euchromatic segments of the chromosomes. AT-rich DNA sequences are known to enhance the intensity of quinacrine, DAPI and Hoechst 33258 fluorescence [Weisblum and de Haseth, 1972; Weisblum, 1973; Comings, 1975; Müller and Gautier, 1975; Lin et al., 1977]. Therefore, heterochromatic regions in amphibian metaphase chromosomes that show bright fluorescence with any of these fluorochromes are believed to be rich in AT base pairs [for reviews, see Schmid et al., 2010, 2012].

As expected from the complementarity of quinacrine and mithramycin staining, the distinct $\mathrm{Q}^{+}$heterochromatic regions located in the karyotypes of $V$. antisthenesi, H. fleischmanni and C. granulosa are always mithramycin-negative. This is especially evident in the chromosomes of $V$. antisthenesi in which the prominent centro- 
Fig. 6. Diploid (a) and tetraploid (b) spermatogonial metaphases of male Vitreorana antisthenesi after distamycin A/mithramycin counterstaining. Chromosomes in $\mathbf{b}$ are arranged as a karyotype in c. Note the mithramycin-negative centromeric and pericentromeric heterochromatin in all autosomes and in the sex chromosomes. Material obtained from testes.
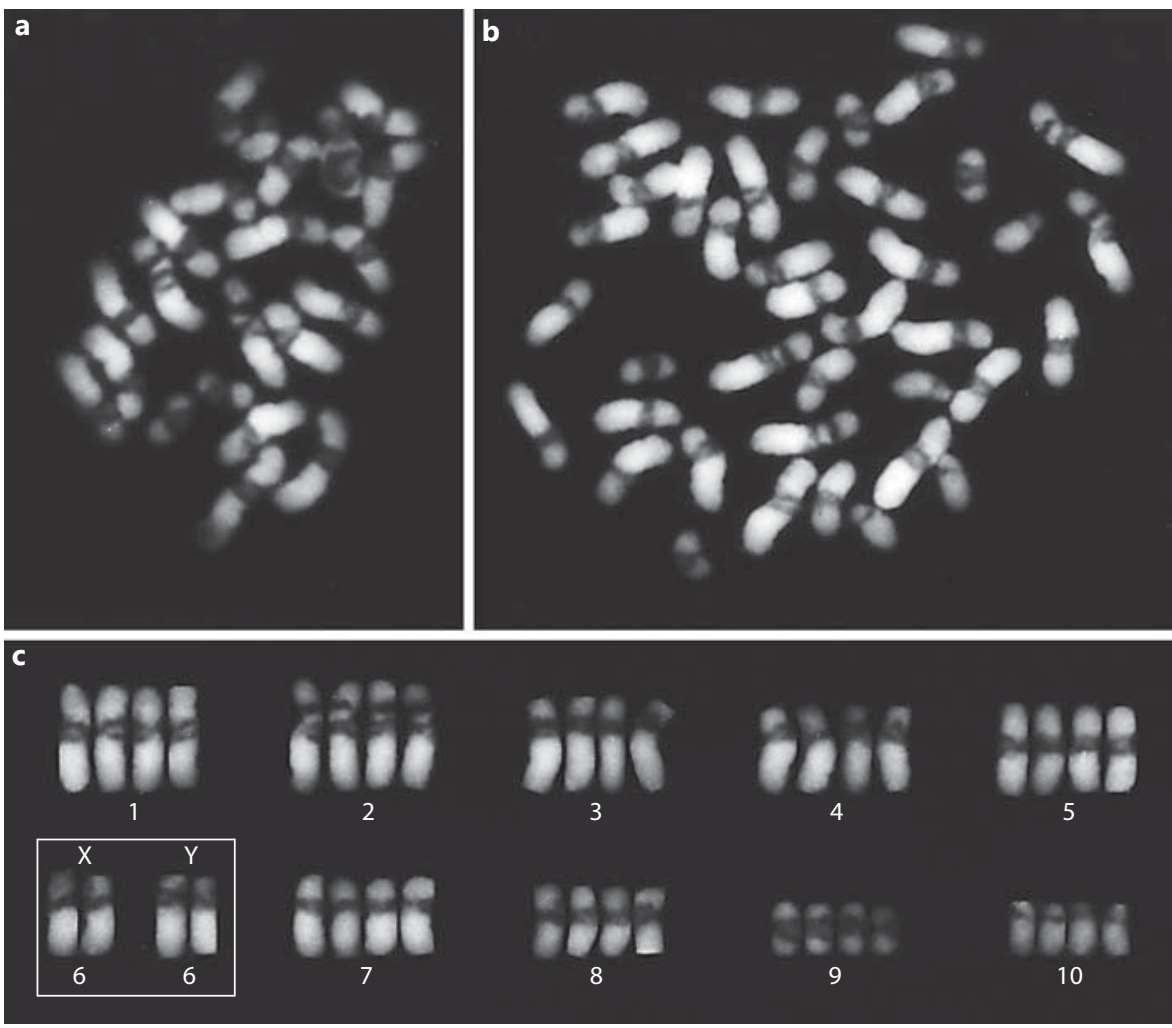

meric and pericentromeric heterochromatin in all chromosomes shows a distinctly quenched mithramycin fluorescence (fig. 6).

\section{Nucleolus Organizer Regions}

Specific silver (Ag-) staining showed that, with the exception of $H$. valerioi, all analyzed centrolenids have a single pair of NORs in their karyotypes (fig. 7). In most species (C. granulosa, V. antisthenesi, H. colymbiphyllum, $H$. duranti, $H$. fleischmanni, $H$. fragile), the NORs are located in short arm paracentromeric regions of chromosomes 1, 2, 4, and 8. In E. prosoblepon, NORs are located in the long arm telomeres of chromosomes 10 (fig. 7b), and in $H$. orientale, they are found in an interstitial position in the long arms of chromosomes 8 (fig. 7h).

In the single specimen of $H$. valerio $i$ that was analyzed, the standard NOR pair is located interstitially in the long arms of chromosomes 9 (fig. 3c). Additionally, ectopic NORs are detected in a telomeric position of 2 other nonhomologous chromosomes. Because of the few metaphases available for analysis, the 2 chromosomes with ectopic NORs could not be identified with certainty. As expected, in the bone marrow and intestine cells of this male individual, 4 Ag-stained nucleoli are present (fig. 3d). Accordingly, in the cells of male meiotic pro- phase, 1 major and 2 smaller nucleoli can be detected (not shown).

\section{Telomeric DNA Sequences}

The patterns of telomeric DNA sequences were examined by FISH in 4 species of centrolenids (C. granulosa, $V$. antisthenesi, $H$. colymbiphyllum, $H$. fleischmanni). In general, the patterns of chromosomal distribution of the canonical (TTAGGG) nepeats are consistent with those in the karyotypes of other amphibians and in a variety of other vertebrates [for reviews, see Schmid et al., 2010, 2012]. In all chromosomes, the (TTAGGG) ${ }_{n}$ repeats are located in the telomeric regions of both chromatids (fig. 8). In the short arms of the smaller chromosomes 9 and 10 , the 2 hybridization signals come together very closely and frequently fuse into a single signal (e.g. fig. 8b, left homolog of chromosome pair 10).

In all analyzed specimens of $V$. antisthenesi, distinct heterochromatic intrachromosomal telomeric sequences (het-ITSs) are located in the constitutive heterochromatin adjacent to the NOR in the short arm of chromosome 2 , and in the paracentromeric heterochromatin of the long arm in one of the homologs 6 (X chromosome). hetITSs are not found in the Y chromosome or the other autosomes (fig. 8b). 


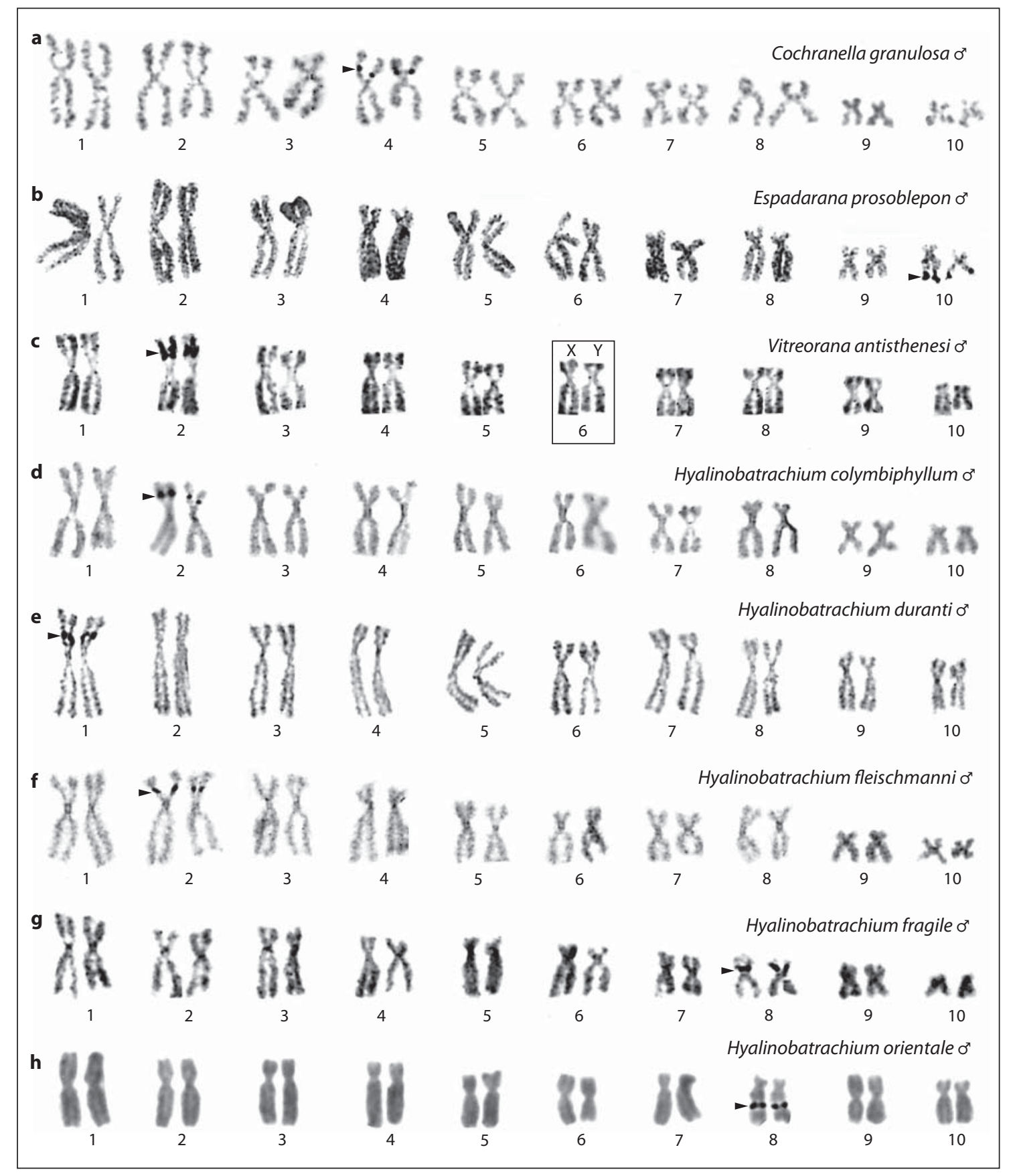

Fig. 7. Ag-stained karyotypes of the centrolenid species examined. The NORs are marked by arrowheads. The heteromorphic XY sex chromosomes of $V$. antisthenesi are framed (c). Material obtained from bone marrow.

\section{Male Meiosis}

As in the male meiosis of almost all highly evolved anurans [Morescalchi, 1973; Schmid et al., 2010, 2012], the diakinetic bivalents of centrolenids are strongly contracted, and most of them show a ring-like or dumb-bellshaped morphology [Duellman and Cole, 1965; Duell- man, 1967; Schmid et al., 1989]. This results from telomerically located chiasmata. In the pachytene stage of prophase in mammalian male meiosis, a sex vesicle is formed by the XY sex chromosomes. A similar vesicle is not found in amphibians. 


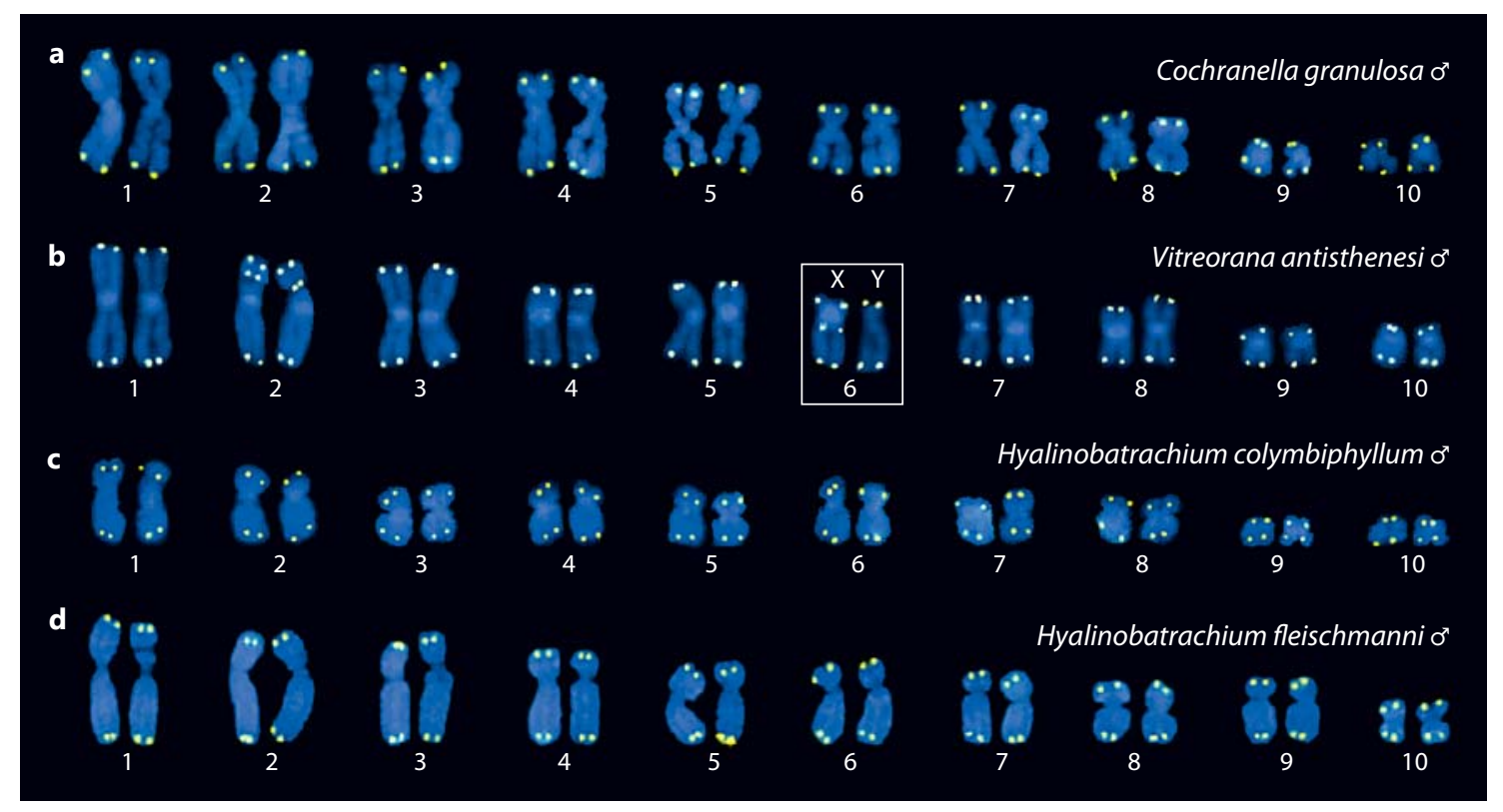

Fig. 8. Karyotypes of 4 centrolenid species showing the FISH patterns of the telomeric (TTAGGG) ${ }_{n}$ repeats. Note the het-ITSs in the short arms of chromosomes 2, and in the long arm pericentromeric heterochromatin of the $\mathrm{X}$ chromosome of $V$. antisthenesi (b). The heteromorphic XY sex chromosomes of $V$. antisthenesi are framed. Material obtained from bone marrow.

In $V$. antisthenesi, the diakinetic XY bivalent can easily be identified by the unequally-sized $\mathrm{Q}^{+}$heterochromatin in their centromeric and paracentromeric regions (fig. 9a-e). One half of the bivalent (X) is brightly labeled by quinacrine, and the opposite half $(\mathrm{Y})$ is characterized by a dull fluorescence. In none of the diakineses observed did the XY chromosomes show an end-to-end association like that found in the male meiosis of several other amphibian species possessing heteromorphic XY chromosomes [for reviews, see Schmid et al., 2010, 2012]. Although the morphology and banding patterns of the $\mathrm{X}$ and $\mathrm{Y}$ chromosomes of $V$. antisthenesi are distinctly heteromorphic, they still show the same pairing configuration as the autosomal bivalents. This could indicate that the euchromatic segments in the XY chromosomes of $V$. antisthenesi are still genetically homologous and that pairing and crossing over occur along them during meiotic prophase. Differentiation among the 9 autosomal bivalents can be achieved by comparing their relative sizes. In the leptotene stage, the $\mathrm{Q}^{+}$heterochromatic chromosome regions can be clearly discerned as individual brightly fluorescing blocks (fig. 9f, g). In contrast to the nuclei of somatic tissues (fig. 10), these heterochromatic regions do not fuse into larger chromocenters. As expected, in the round spermatid nuclei, a maximum of 10

Chromosome Banding in Amphibia. XXXI. Centrolenidae and Allophrynidae brightly fluorescing heterochromatic regions are present (fig. 9h).

\section{Somatic Interphase Nuclei}

In the majority of interphase nuclei from bone marrow and intestine of $V$. antisthenesi, the 20 large centromeric and paracentromeric heterochromatic regions of the chromosomes are fused into a few chromocenters (fig. 10a-d). As was first shown in Hemiptera [Slack, 1938; Schrader, 1941], one of the general features of constitutive heterochromatin is its tendency for different heterochromatic regions to enter into non-specific temporary or permanent associations. In polytene Drosophila nuclei, the pericentromeric heterochromatin of all chromosomes becomes permanently fused to form a large chromocenter, and many intercalary heterochromatic bands demonstrate so-called 'ectopic pairing' [Slizynski, 1945; Kaufmann and Iddles, 1963]. Ectopic pairing of heterochromatic regions also exists in mammalian interphase nuclei [Hsu et al., 1971; Rae and Francke, 1972], including metaphases of human chromosomes [Schmid et al., 1975, 1981, 1983]. Ectopic pairing occurs most frequently between the heterochromatin of homologous chromosomes but can also occur between non-homologous chromosomes, although the first type is, in statistical 

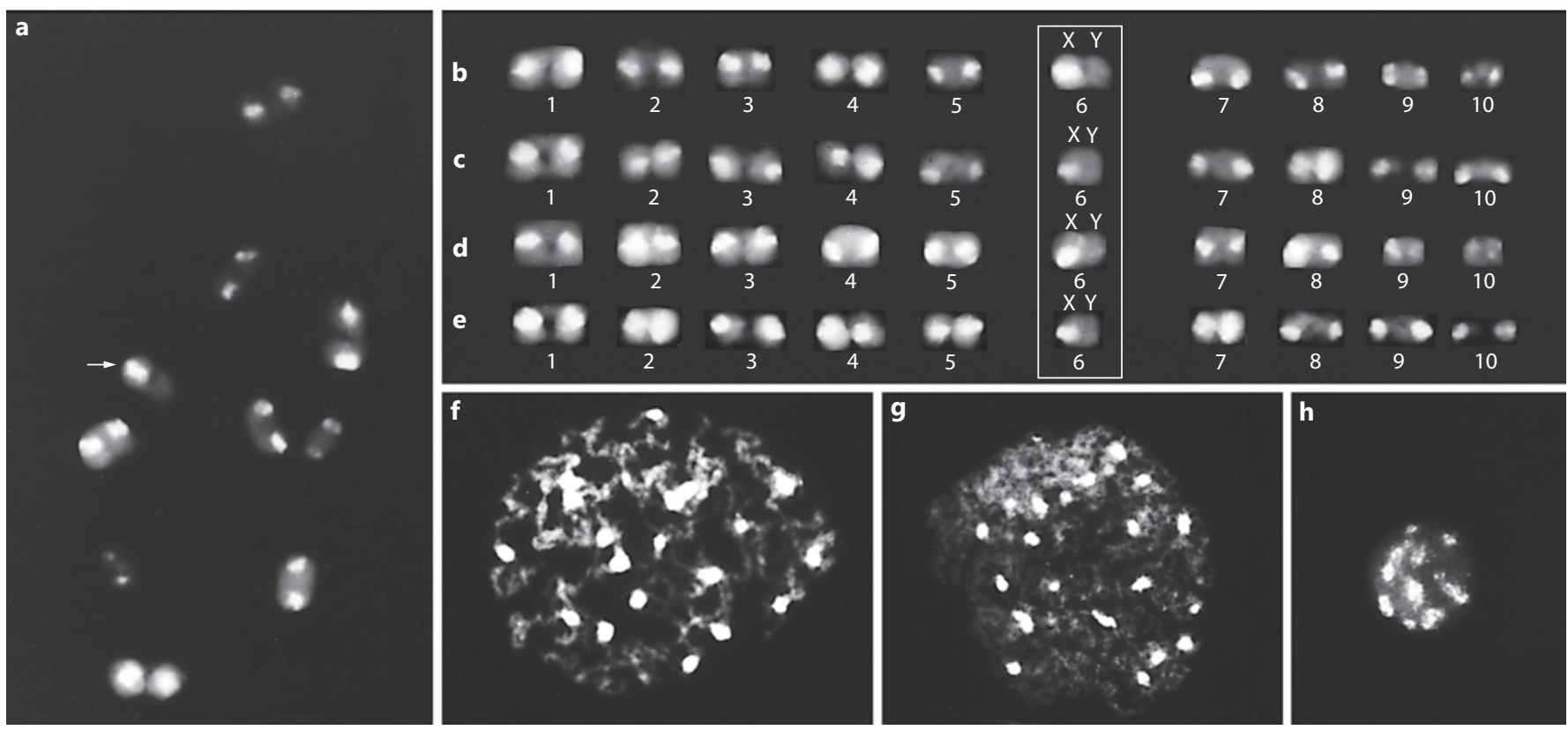

Fig. 9. Diakinesis (a) and bivalents (b-e) of 4 diakineses of male meiosis in Vitreorana antisthenesi after staining with quinacrine mustard. In a the XY bivalent is marked by an arrow, in $\mathbf{b}-\mathbf{e}$ the XY bivalents are framed. $\mathbf{f}-$ h Quinacrine-stained leptotene nuclei $(\mathbf{f}, \mathbf{g})$ and early spermatid nucleus (h) of $V$. antisthenesi. Note the brightly fluorescing heterochromatic chromocenters. Material obtained from testes.

terms, more frequent [Haaf et al., 1986]. The existence of repetitive DNA-containing physical connections between metaphase chromosomes has been demonstrated to occur in mouse and human cell lines by Kuznetsova et al. [2007]. In mitotic metaphase chromosomes of the terraranan frog Pristimantis fenestratus, chromatin connections were found between heterochromatic regions in telomere-telomere, centromere-centromere and centromere-telomere configurations [Siqueira et al., 2009]. It seems conceivable, but not yet experimentally proven, that the phenomenon of ectopic pairing is mediated by a complete (or at least partial) homology of the base pairs in the repetitive DNA of heterochromatin.

In some of the bone marrow interphase nuclei of $V$. antisthenesi, the large compact heterochromatic chromocenters have split up into smaller ones with diffuse boundaries (fig. 10e-h). The most plausible explanation is that these nuclei are in the S-phase of the cell cycle in which the compact structure of the constitutive heterochromatin decondenses in order to facilitate replication.

\section{Genome Sizes}

The genome sizes of 4 centrolenid species ( $V$. antisthenesi, $H$. colymbiphyllum, $H$. fleischmanni, and H. orientale) were determined in the present study. All measure- ments were performed using DNA flow cytometry of DAPI-stained erythrocytes obtained from male specimens. As examples of these measurements, the histograms obtained for $V$. antisthenesi and $H$. orientale are shown in figure 11. V. antisthenesi has the lowest genome size $(6.20$ pg DNA/nucleus), whereas those of $H$. colymbiphyllum, $H$. fleischmanni and $H$. orientale are distinctly higher (10.65, 8.98 and $8.70 \mathrm{pg}$ DNA/nucleus, respectively). The coefficient of variation of the measurements ranged between 2 and $2.7 \%$.

It should be noted that the erythrocytes were stained with the AT base pair-specific DAPI, and not with ethidiumbromide which anneals to double-stranded DNA regardless of its base pair composition. Therefore, erythrocyte nuclei of $V$. antisthenesi, with high amounts of AT-rich repetitive DNA in the $\mathrm{Q}^{+}$constitutive heterochromatin (see above), will be more intensively labeled than those of species depauperate in such sequences or with enriched amounts of GC-repetitive DNA in their heterochromatic chromosome regions. If so, this would lead to a biased, somewhat higher DNA value in $V$. antisthenesi. In spite of this, the results obtained by DNA flow cytometry do allow for general conclusions with respect to genome sizes in the Centrolenidae. 
Fig. 10. C-banded interphase nuclei of $\mathrm{Vi}$ treorana antisthenesi. a-d The centromeric and paracentromeric heterochromatic regions of the chromosomes are fused into a few large chromocenters. e-h The compact chromocenters have split up and decondensed probably due to replication of the constitutive heterochromatin in the late Sphase. Material obtained from bone marrow.

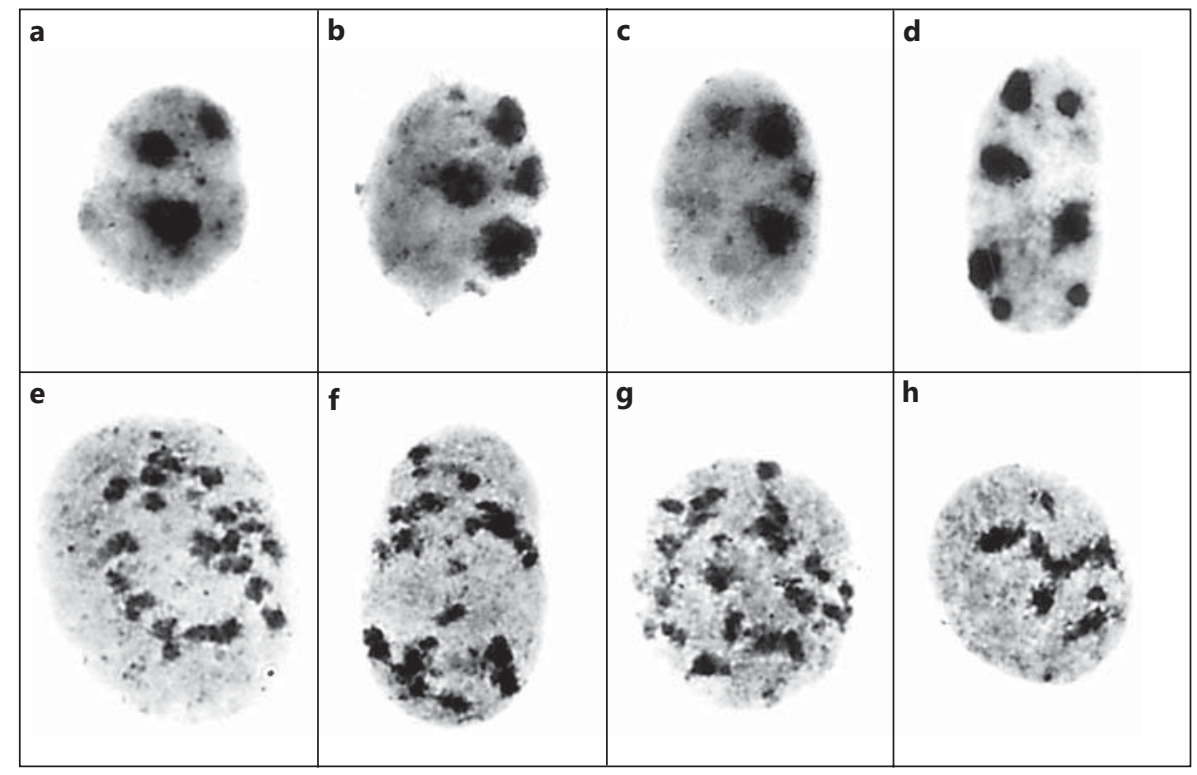

\section{Discussion}

Anuran species with a diploid chromosome number of $2 n=20$ or lower are not very frequent [for reviews, see King, 1990; Green and Sessions, 2007]. The comparative cytogenetic analyses presented here show that the karyotypes of the Centrolenidae and Allophrynidae have been rather conserved during evolution. The minor differences existing between the chromosome lengths in the various species can be easily explained by the occurrence of pericentric inversions, unequal reciprocal translocations, chromosomal shifts, and changes in the amount of constitutive heterochromatin. Such mutations have been successfully fixed in a homozygous condition in the karyotypes since the different species have diverged.

According to Morescalchi [1973], the low chromosome number of $2 n=20$ encountered in the Centrolenidae can be derived from a $2 n=24$ or 22 karyotype found in many South and Central American species of the family Hylidae to which the Centrolenidae seemed to be phylogenetically related [Noble, 1931; Taylor, 1951; Lynch, 1973]. Other studies, however, using molecular techniques [Austin et al., 2002; Biju and Bossuyt, 2003; Darst and Cannatella, 2004; Faivovich et al., 2005; Frost et al., 2006; Grant et al., 2006; Roelants et al., 2007] or phenotypical characters [Ford and Cannatella, 1993; Duellman and Trueb, 1994; Rueda-Almonacid, 1994; Duellman, 2001; Haas, 2003; Burton, 2004; Wiens et al., 2005] could not resolve with confidence the phylogenetic position of the Centrolenidae within the Neobatrachia.

Since A. ruthveni was first described [Gaige, 1926], it has been placed within the families Bufonidae, Centrolenidae, Hylidae, and Leptodactylidae [for a review, see Caldwell and Hoogmoed, 1998] or within its own family Allophrynidae [Savage, 1973, 1986; Goin et al., 1978]. A study using DNA sequence data from 2 mitochondrial genes ( $16 \mathrm{~S}+12 \mathrm{~S}$ ribosomal RNA) suggests that $A$. ruth$v e n i$ is most closely allied to the family Centrolenidae [Austin et al., 2002]. Further molecular phylogenetic studies analyzing the $16 \mathrm{~S}+12 \mathrm{~S}$ rRNA genes and the intervening transfer RNA valine gene [Lourenço et al., 2008], or the mitochondrial $16 \mathrm{~S}+12 \mathrm{~S}$ rRNA and $\mathrm{NADH}$ 1 genes, as well as the nuclear genes $c-m y c, P O M C$ and RAG-1 [Guayasamin et al., 2008], have confirmed that $A$. ruthveni is a sister taxon to the family Centrolenidae. This is consistent with Noble [1931] who originally designated A. ruthveni as an edentate centrolenid. In conclusion, and as stated by Guayasamin et al. [2009], there are sufficient data to conclude that there is a close evolutionary relationship between the Centrolenidae and Allophrynidae, whereas the relationships of this clade with other anurans are still unclear.

The sister group relationship between the Centrolenidae and Allophrynidae (unranked taxon Allocentroleniae) is clearly corroborated by the present cytogenetic study which demonstrates a conservation of the diploid chromosome number and a high degree of similarity of 


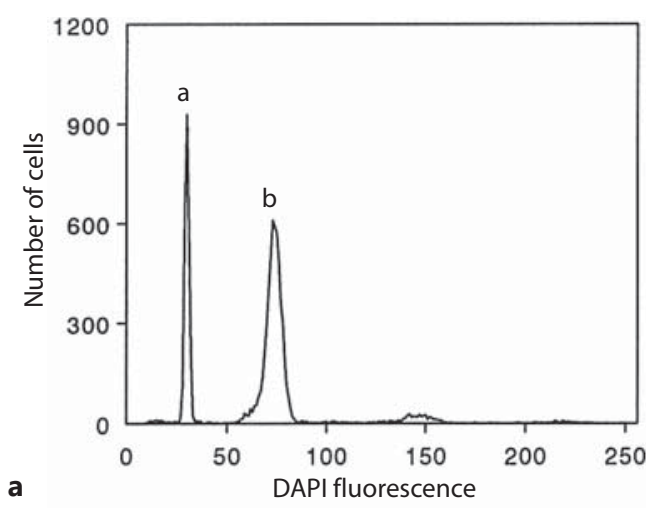

1999, 2003; Griffin et al., 1999; Campos-Ramos et al., 2001; Phillips et al., 2001; Rens et al., 2001, 2003, 2004, 2006; Harvey et al., 2002; Liu et al., 2002; Guttenbach et al., 2003; Grützner et al., 2004; Nanda et al., 2006, 2007, 2008; Ferguson-Smith and Trifonov, 2007; Henning et al., 2008; Giovanotti et al., 2009; Cioffi et al., 2013].

Previous cytogenetic studies on NORs in Anura clearly demonstrate that the overwhelming majority of species possess only a single 'standard' pair of NORs [Schmid, 1980; King, 1990; Green and Sessions, 2007; Schmid et al., 2010, 2012]. This is also the case in the Centrolenidae with the exception of $H$. valerioi. Intraspecific polymorphisms in the number and location of the NORs have not been detected in the specimens examined. In the karyotypes of the 9 species examined by Ag-staining, the standard NOR pair is located in the chromosomes 1, 2, 4, 8, 9, or 11. Provided that all chromosome pairs of the centrolenids have maintained their evolutionary homeology, the different NOR locations can be best explained by chromosomal shifts which specifically transferred the NORs between the chromosomes without causing gross alterations of their morphologies. The possible molecular mechanism responsible for the NOR transfer has been discussed in detail by Schmid et al. [2010, 2012].

In $V$. antisthenesi, 2 interstitial clusters of the telomeric hexanucleotide (TTAGGG) $)_{\mathrm{n}}$ are present in the NORassociated heterochromatin in the short arm of autosome

Fig. 11. Histograms obtained by DNA flow cytometry of a mixture of DAPI-stained erythrocytes of chicken and male individuals of Vitreorana antisthenesi (a) and Hyalinobatrachium orientale (b). The nuclear DNA content is directly proportional to the DAPI fluorescence intensity, expressed as channel numbers on the $\mathrm{x}$ axis. Chicken erythrocytes (peak a) were used as internal standards with a known DNA content of $2.33 \mathrm{pg}$ DNA/nucleus. The nuclear DNA content of the frog erythrocytes is calculated from the ratio of the peak channel number of the frog erythrocytes (peaks $b$ and c) and chicken (peak a) multiplied by the known nuclear DNA amount of the chicken.

chromosome morphology (homeology) in all species examined. The origin of the minor changes existing in the chromosome morphology can be elucidated, at least partially, with the help of modern molecular cytogenetic methods such as cross-species chromosome painting using chromosome-specific DNA probes generated from flow-sorted or microdissected chromosomes that are used as templates for DNA amplification by DOP-PCR. Such experiments have been successfully performed for comparative cytogenetic studies in mammals, birds, reptiles, and fishes [e.g. Reed et al., 1995; Yang et al., 1995,

2 and in the paracentromeric heterochromatin of the $\mathrm{X}$ long arm. Such het-ITSs have also been demonstrated in the karyotypes of a variety of other anuran species. The (TTAGGG) $)_{n}$ repeats in het-ITSs can span up to several hundred $\mathrm{kb}$ and are predominantly located in constitutive heterochromatin. It is conceivable that het-ITSs are relics of chromosomal repatterning that occurred during karyotype evolution and shifted telomeric (TTAGGG) repeats into internal positions [for reviews, see Schmid et al., 2010, 2012]. Chromosome rearrangements, capable to internalize telomeric (TTAGGG) ${ }_{n}$ repeats are mainly centric (Robertsonian) fusions, inversions, tandem translocations and insertions. Given the apparent numerical stability of centrolenid karyotypes, centric fusions and tandem translocations seem to be unlikely for the origin of the het-ITSs in $V$. antisthenesi. Thus, either inversions or insertions likely caused these het-ITSs, or alternatively, these (TTAGGG) $)_{n}$ repeats are simply components of the highly repetitive DNA sequences of heterochromatic regions. In this case, a partial or complete sequence identity of the telomeric DNA and the repetitive DNA of the heterochromatic regions is purely coincidental. The (TTAGGG) $)_{n}$ repeat is known to be a component of the 
repetitive satellite DNAs of some vertebrates [Southern, 1970; Fry and Salser, 1977; Arnason et al., 1988].

The present data confirm the existence of heteromorphic XY sex chromosomes in $V$. antisthenesi, initially observed by Schmid et al. [1989] in 2 males and females (table 1). Cytogenetically demonstrable sex chromosomes, either of the $\mathrm{XY} \sigma^{-1} / \mathrm{XX}$ or $\mathrm{ZW} / \mathrm{ZZ \sigma ^{ \prime }}$ type, are known to exist but are exceptional in amphibians. According to the Tree of Life database (http://tolweb.org/ Salientia/14938), there are 172 extant species of Gymnophiona, 557 species of Urodela, and 5,424 extant species of Anura. Although approximately one third of these 6,153 extant amphibians have been karyotyped [listed by Green and Sessions, 2007], only about 5\% of those species have demonstrated morphologically distinguishable sex chromosomes. The most recent compilations on anuran sex chromosomes, including those of $V$. antisthenesi, document the existence of only 42 species possessing microscopically detectable sex chromosomes [Schmid et al., 2010, 2012]. The heteromorphic XY sex chromosomes of $V$. antisthenesi are distinguished by several features which, in combination, are not encountered in any of the other anuran sex chromosomes. They can be interpreted as $\mathrm{XY}$ chromosomes in a nascent stage of morphological differentiation, still of approximately the same length and only differing slightly in the positions of their centromeres. Chromosome banding analyses, however, reveal a conspicuous heteromorphism. Thus, there is more telomeric heterochromatin located in the $\mathrm{Y}$ long arm than in the $\mathrm{X}$ long arm. This is in agreement with most cytogenetic and molecular studies on lower vertebrates which demonstrate that the accumulation of repetitive DNA sequences in the $\mathrm{Y}$ or $\mathrm{W}$ chromosome is the primary step [Singh et al., 1976, 1980, 1981; Jones, 1984; Schmid et al., 2010, 2012]. The centromeric and pericentromeric heterochromatin in the $\mathrm{Y}$ chromosome has a higher sensitivity to alkaline $\mathrm{Ba}(\mathrm{OH})_{2}$ treatment (necessary for the demonstration of C-bands) than the heterochromatin in the $\mathrm{X}$ chromosome. Finally, only the centromeric and not the pericentromeric heterochromatin is stained with the AT base pair-specific quinacrine in the $\mathrm{Y}$ chromosome, whereas both of these are brightly labeled in the X chromosome and autosomes. The fact that the banding patterns in the $\mathrm{X}$ chromosome strongly resemble those in the autosomes of $V$. antisthenesi indicates that it has largely conserved its original organization and that the structurally more complex $\mathrm{Y}$ is evolutionarily derived.

According to King [1990], Gregory [2005] and the Animal Genome Size Database (http://www.genomesize. com), there are no data on genome sizes for any centro- lenid or allophrynid species. The values measured in the present study for 4 centrolenids range between 6.20 and $10.65 \mathrm{pg}$ DNA/nucleus. The known genome sizes in the order Anura range from 1.90 to $19.71 \mathrm{pg} \mathrm{DNA}$ /nucleus. The frequencies of diploid anuran genome sizes show a clear unimodal distribution, with a value between 8 and 10 pg DNA/nucleus [reviewed in Schmid et al., 2010]. Thus, the genome sizes of the centrolenids seem to fit quite well in this frequency distribution.

The phylogenetic relationships of the Allocentroleniae within the Neobatrachia has not been resolved. Therefore, it is premature to speculate on the various chromosome mutational events that have led from hypothetical ancestral anuran karyotypes with higher chromosome numbers to the reduced $2 n=20$ karyotypes of the Centrolenidae and Allophrynidae. Furthermore, the 11 species analyzed in the present study represent only a very small fraction $(7 \%)$ of all recognized extant species in the Centrolenidae (145 species) and in the Allophrynidae (3 species). Before general conclusions can be drawn, a representative number of species of all genera must be cytogenetically analyzed.

\section{Acknowledgements}

We are indebted to the personnel of the Instituto de Zoología Agricola, University of Venezuela (Maracay) and the Departamento de Biología, University of Costa Rica (San José) for assistance. We thank Dr. Pedro León (Costa Rica) and Dr. Alberto Fernández Badillo (Venezuela) for establishing temporary cytogenetic laboratories. Dr. Hinrich Kaiser provided logistic help on Tobago and Dr. Miguel Rodrigues assisted with permit 005/97DIFAS-IBAMA to collect Allophryne ruthveni in Brazil. The dedicated field work of Roland Weimer in Costa Rica and of Dr. Andrew Chek in Brazil, and the careful cytogenetic analyses of Melanie Hidding in Würzburg are highly appreciated. This study was supported by the Deutsche Forschungsgemeinschaft (Schm 484/71, 10-1, 15-1, 15-2), the Volkswagen Foundation (VW/I/72 515), and a Natural Science and Engineering Research Council of Canada Disvovery Grant to J.P.B.

References Arnason U, Allerdice PW, Lien J, Widegren B: Highly repetitive DNA in the baleen whale genera Balaenoptera and Megaptera. J Mol Evol 27:217-221 (1988).

- Austin JD, Lougheed SC, Tanner K, Chek AA, Bogart JP, Boag PT: A molecular perspective on the evolutionary affinities of an enigmatic neotropical frog, Allophryne ruthveni. Zool J Linn Soc 134:335-346 (2002).

-Biju SD, Bossuyt F: New frog family from India reveals an ancient biogeographical link with the Seychelles. Nature 425:711-714 (2003). 
Bogart JP: Evolution of anuran karyotypes, in Vial JL (ed): Evolutionary Biology of the Anurans, pp 337-349 (University of Missouri Press, Columbia 1973).

Burton TC: Muscles of the pes of hylid frogs. J Morph 260:209-233 (2004).

Caldwell JP, Hoogmoed MS: Allophrynidae, $\mathrm{Al}$ lophryne, A. ruthveni. Catalogue of American Amphibians and Reptiles 666:1-3 (1998).

-Campos-Ramos R, Harvey SC, Masabanda JS, Carrasco LA, Griffin DK, et al: Identification of putative sex chromosomes in the blue tilapia, Oreochromis aureus, through synaptonemal complex and FISH analysis. Genetica 111: 143-153 (2001).

Cannatella DC, Duellman WE: Two new species of Centrolenella, with a brief review of the genus in Peru and Bolivia. Herpetologica 33: 380-388 (1982).

-Caramaschi U, Orrico VGD, Faivovich J, Dias I, Solé M: A new species of Allophryne (Anura: Allophrynidae) from the Atlantic rain forest biome of eastern Brazil. Herpetologica 69: 480-491 (2013).

-Castroviejo-Fisher S, Pérez-Peña PE, Padial JM, Guayasamin JM: A second species of the family Allophrynidae (Amphibia: Anura). Am Mus Novit 3739:1-17 (2012).

Cioffi MB, Liehr T, Trifonov V, Molina WF, Bertollo LAC: Independent sex chromosome evolution in lower vertebrates: a molecular cytogenetic overview in the Erythrinidae fish family. Cytogenet Genome Res 141:186-194 (2013).

Cisneros-Heredia DF, McDiarmid RW: Revision of the characters of Centrolenidae (Amphibia: Anura: Athesphatanura), with comments on its taxonomy and the description of new taxa of glassfrogs. Zootaxa 1572:1-82 (2007).

Comings DE: Mechanisms of chromosome banding. VIII. Hoechst 33258-DNA interaction. Chromosoma 52:229-243 (1975).

- Darst CR, Cannatella DC: Novel relationships among hyloid frogs inferred from $12 S$ and $16 S$ mitochondrial DNA sequences. Mol Phylogenet Evol 31:462-475 (2004).

Duellman WE: Additional studies of chromosomes of anuran amphibians. Syst Zool 16: 38-43 (1967).

Duellman WE: Liste der rezenten Amphibien und Reptilien. Hylidae, Centrolenidae, Pseudidae, in Mertens T, Hennig W (eds): Das Tierreich 95 (de Gruyter, Berlin 1977).

Duellman WE: Hylid Frogs of Middle America (Society for the Study of Amphibians and Reptiles, Ithaca, New York 2001).

Duellman WE, Burrowes PA: New species of frogs, Centrolenella, from the Pacific versant of Ecuador and southern Colombia. Occas Pap Mus Nat Hist Univ Kansas 132:1-14 (1989).

Duellman WE, Cole CJ: Studies of chromosomes of some anuran amphibians (Hylidae and Centrolenidae). Syst Zool 14:139-143 (1965).

Duellman WE, Trueb L: Biology of the Amphibians (Johns Hopkins University Press, Baltimore 1994)
Faivovich J, Haddad CFB, García PCA, Frost DR, Campbell JA, Wheeler WC: Systematic review of the frog family Hylidae, with special reference to Hylinae: phylogenetic analysis and taxonomic revision. Bull Am Nat Hist 294:1-240 (2005).

Ferguson-Smith MA, Trifonov V: Mammalian karyotype evolution. Nat Rev Genet 8:950962 (2007).

Ford LS, Cannatella DC: The major clades of frogs. Herpetol Monogr 7:94-117 (1993).

-Frost DR, Grant T, Faivovich J, Bain RH, Haas A, et al: The amphibian tree of life. Bull Am Nat Hist 297:1-370 (2006).

-Fry K, Salser W: Nucleotide sequences of HS- $\alpha$ satellite DNA from kangaroo rat Dipodomys ordi and characterization of similar sequences in other rodents. Cell 12:1069-1084 (1977).

Gaige HT: A new frog from British Guiana. Occas Pap Mus Zool Univ Mich 176:1-3 (1926).

-Giovanotti M, Caputo V, O’Brien PCM, Lovell FL, Trifonov V, et al: Skinks (Reptilia: Scincidae) have highly conserved karyotypes as revealed by chromosome painting. Cytogenet Genome Res 127:224-231 (2009).

Goin CJ, Goin OB, Zug GR: Introduction to Herpetology (Freeman, San Francisco 1978).

- Grant T, Frost DR, Caldwell JP, Gagliardo R, Haddad CFB, et al: Phylogenetic systematics of dart-poison frogs and their relatives (Amphibia: Athesphatanura: Dendrobatidae). Bull Am Nat Hist 299:1-262 (2006).

Green DM, Sessions SK: Karyology and cytogenetics, in Heatwole $\mathrm{H}$, Tyler M (eds): Amphibian Biology, Vol 7 (Surrey Beatty \& Sons, Chipping Norton 2007).

Gregory TR: Genome size evolution in animals, in Gregory TR (ed): The Evolution of the Genome, pp 3-87 (Elsevier/Academic Press, Burlington 2005).

Griffin DK, Haberman F, Masabanda J, O’Brien $\mathrm{P}$, Bagga $\mathrm{M}$, et al: Micro- and macrochromosome paints generated by flow cytometry and microdissection: tools for mapping the chicken genome. Cytogenet Cell Genet 87:278-281 (1999).

Grützner F, Rens W, Tsend-Ayush E, El-Mogharbel N, O'Brien PCM, et al: In the platypus a meiotic chain of ten sex chromosomes shares genes with the bird $\mathrm{Z}$ and mammal $\mathrm{X}$ chromosomes. Nature 432:913-917 (2004).

- Guayasamin JM, Castroviejo-Fisher S, Ayarzagüena J, Trueb L, Vilà C: Phylogenetic relationships of glassfrogs (Centrolenidae) based on mitochondrial and nuclear genes. Mol Phylogenet Evol 48:574-595 (2008).

Guayasamin JM, Castroviejo-Fisher S, Trueb L, Ayarzagüena J, Rada M, Vilà C: Phylogenetic systematics of glassfrogs (Amphibia: Centrolenidae) and their sister taxon Allophryne ruthveni. Zootaxa 2100:1-97 (2009).

Guttenbach M, Nanda I, Feichtinger W, Masabanda JS, Griffin DK, Schmid M: Comparative chromosome banding of chicken autosomal paints 1-9 in nine different bird species. Cytogenet Genome Res 103:173-184 (2003).
Haaf T, Steinlein K, Schmid M: Preferential somatic pairing between homologous heterochromatic regions of human chromosomes. Am J Hum Genet 38:319-329 (1986).

Haas A: Phylogeny of frogs as inferred from primarily larval characters (Amphibia: Anura). Cladistics 19:23-89 (2003).

-Harvey SC, Masabanda J, Carrasco LA, Bromage NR, Penman DJ, Griffin DK: Molecular-cytogenetic analysis reveals sequence differences between the sex chromosomes of Oreochromis niloticus: evidence for an early stage of sex-chromosome differentiation. Cytogenet Genome Res 97:76-80 (2002).

-Henning F, Trifonov V, Ferguson-Smith MA, de Almeida-Toledo LF: Non-homologous sex chromosomes in two species of the genus $\mathrm{Ei}$ genmannia (Teleostei: Gymnotiformes). Cytogenet Genome Res 121:55-58 (2008).

Hsu TC, Cooper JEK, Mace ML, Brinkley BR: Arrangement of centromeres in mouse cells. Chromosoma 34:73-87 (1971).

- Jones KW: The evolution of sex chromosomes and their consequences for the evolutionary process, in Bennett MD, Gropp A, Wolf U (eds): Chromosomes Today, vol 8, pp 241255 (George Allen \& Unwin, London 1984).

Kaufmann BP, Iddles MK: Ectopic pairing in salivary gland chromosomes of Drosophila melanogaster. I. Distributional patterns in relation to puffing. Port Acta Biol A 7:225-248 (1963).

King M: Amphibia, in John B (ed): Animal Cytogenetics, Vol 4/2 (Gebrüder Borntraeger, Berlin 1990).

Kubicki B: Glassfrogs of Costa Rica (Editorial INBio, Santo Domingo de Heredia 2007).

Kuznetsova IS, Enukashvily NI, Noniashvili EM, Shatrova AN, Aksenov ND, et al: Evidence for the existence of satellite DNA-containing connection between metaphase chromosomes. J Cell Biochem 101:1046-1061 (2007).

Langone JA, Segalla MV: Ampliación de la distribución del género Allophryne (Amphibia, Anura, Allophrynidae). Cuadernos de Herpetología 11:87-88 (1997).

León PE: Report of the chromosome numbers of some Costa Rican anurans. Rev Biol Trop 17: 119-124 (1970).

Lin MS, Comings DE, Alfi OS: Optical studies of the interaction of 4'-6-diamidino-2-phenylindole with DNA and metaphase chromosomes. Chromosoma 60:15-25 (1977).

Liu JD, Yi MS, Zhao G, Zhou F, Wang DQ, Yu QX: Sex chromosomes in the spiny eel (Mastacembelus aculeatus) revealed by mitotic and meiotic analysis. Cytogenet Genome Res 98: 291-297 (2002).

Lourenço LB, Bacci-Júnior M, Martins VG, Recco-Pimentel SM, Haddad CFB: Molecular phylogeny and karyotype differentiation in Paratelmatobius and Scythrophrys (Anura, Leptodactylidae). Genetica 132:255-266 (2008)

Lynch JD: The transition from archaic to advanced frogs, in Vial JL (ed): Evolutionary Biology of the Anurans, pp 133-182 (University of Missouri Press, Columbia 1973). 
Morescalchi A: Amphibia, in Chiarelli AB, Capanna E (eds): Cytotaxonomy and Vertebrate Evolution, pp 233-348 (Academic Press, London 1973).

Müller W, Gautier F: Interactions of heterochromatic compounds with nucleic acids. AT-specific non-intercalating DNA ligands. Eur J Biochem 54:385-394 (1975).

-Nanda I, Karl E, Volobouev V, Griffin DK, Schartl $\mathrm{M}$, Schmid M: Extensive gross genomic rearrangements between chicken and Old World vultures (Falconiformes: Accipitridae). Cytogenet Genome Res 112:286-295 (2006).

- Nanda I, Karl E, Griffin DK, Schartl M, Schmid M: Chromosome repatterning in three representative parrots (Psittaciformes) inferred from comparative chromosome painting. $\mathrm{Cy}$ togenet Genome Res 117:43-53 (2007).

-Nanda I, Schlegelmilch K, Haaf T, Schartl M, Schmid M: Synteny conservation of the $\mathrm{Z}$ chromosome in 14 avian species (11 families) supports a role for $\mathrm{Z}$ dosage in avian sex determination. Cytogenet Genome Res 122: 150-156 (2008).

Noble GK: The Biology of Amphibia (McGrawHill, New York 1931).

-Otto FJ: High-resolution analysis of nuclear DNA employing the fluorochrome DAPI, in Darzynkiewicz Z, Robinson JP, Crissman HA (eds): Methods in Cell Biology, Vol 41, Flow Cytometry, pp 211-217 (Academic Press, San Diego 1994).

- Phillips RB, Konkol NR, Reed KM, Stein JD: Chromosome painting supports lack of homology among sex chromosomes in Oncorhynchus, Salmo, and Salvelinus (Salmonidae). Genetica 111:119-123 (2001).

-Rae PMM, Francke WW: The interphase distribution of satellite DNA-containing heterochromatin in mouse nuclei. Chromosoma 39 : 443-456 (1972).

-Reed KM, Bohlander SK, Phillips RB: Microdissection of the Y chromosome and fluorescence in situ hybridization analysis of the sex chromosomes of lake trout, Salvelinus namaycush. Chromosome Res 3:221-226 (1995).

Rens W, O’Brien PCM, Yang F, Solanky N, Perelman $P$, et al: Karyotype relationships between distantly related marsupials from South America and Australia. Chromosome Res 9: 301-308 (2001).

-Rens W, O’Brien PCM, Fairclough H, Harman L, Graves JAM, Ferguson-Smith MA: Reversal and convergence in marsupial chromosome evolution. Cytogenet Genome Res 102:282290 (2003)

-Rens W, Grützner F, O’Brien PCM, Fairclough H, Graves JAM, Ferguson-Smith MA: Resolution and evolution of the duck-billed platypus karyotype with an X1Y1X2Y2X3Y3X4Y4X5Y5 male sex chromosome constitution. Proc Natl Acad Sci USA 101:16257-16261 (2004).
Rens W, Fu B, O’Brien PCM, Ferguson-Smith MA: Cross-species chromosome painting. Nat Protoc 1:783-790 (2006).

Roelants K, Gower DJ, Wilkinson M, Loader SP Biju SD, et al: Global patterns of diversification in the history of modern amphibians. Proc Natl Acad Sci USA 104:887-892 (2007).

Rueda-Almonacid JV: Estudio anatómico y relaciones sistemáticas de Centrolene geckoideum (Salientia: Anura: Centrolenidae). Trianea 5: 133-187 (1994).

Ruiz-Carranza PM, Lynch JD: Ranas Centrolenidae de Colombia. I. Propuesta de una nueva clasificación genérica. Lozania 57:1-30 (1991).

Savage JM: The geographic distribution of frogs, in Vial JL (ed): Evolutionary Biology of the Anurans, pp 351-445 (University of Missouri Press, Columbia 1973).

Savage JM: Nomenclatural notes on the Anura (Amphibia). Proc Biol Soc Wash 99:42-45 (1986).

Schmid M: Chromosome banding in Amphibia. I. Constitutive heterochromatin and nucleolus organizer regions in Bufo and Hyla. Chromosoma 66:361-388 (1978a).

Schmid M: Chromosome banding in Amphibia. II. Constitutive heterochromatin and nucleolus organizer regions in Ranidae, Microhylidae and Rhacophoridae. Chromosoma 68: 131-148 (1978b).

Schmid M: Chromosome evolution in Amphibia, in Müller H (ed): Cytogenetics of Vertebrates, pp 4-27 (Birkhäuser, Basel 1980).

-Schmid M, Vogel W, Krone W: Attraction between centric heterochromatin of human chromosomes. Cytogenet Cell Genet 15:6680 (1975).

Schmid M, Poppen A, Schmid W, Engel W: Somatic pairings of the $\mathrm{Y}$ heterochromatin in human XYY and XYqi cells. Cytogenet Cell Genet 29:203-214 (1981).

Schmid M, Grunert D, Haaf T, Engel W: A direct demonstration of somatically paired heterochromatin of human chromosomes. Cytogenet Cell Genet 36:554-561 (1983).

-Schmid M, Vitelli L, Batistoni R: Chromosome banding in amphibia. XI. Constitutive heterochromatin, nucleolus organizers, $18 \mathrm{~S}+28 \mathrm{~S}$ and $5 S$ ribosomal RNA genes in Ascaphidae, Pipidae, Discoglossidae and Pelobatidae. Chromosoma 95: 271-284 (1987).

Schmid M, Steinlein C, Feichtinger W: Chromosome banding in Amphibia. XIV. The karyotype of Centrolenella antisthenesi (Anura, Centrolenidae). Chromosoma 97:434-438 (1989).

-Schmid M, Steinlein C, Bogart JP, Feichtinger W, León $\mathrm{P}$, et al: The chromosomes of terraranan frogs. Insights into vertebrate cytogenetics. Cytogenet Genome Res 130/131:1-568 (2010).
Schmid M, Steinlein C, Bogart JP, Feichtinger W, Haaf T, et al: The hemiphractid frogs. Phylogeny, embryology, life history, and cytogenetics. Cytogenet Genome Res 138:69-384 (2012).

- Schrader F: Heteropycnosis and non-homologous association of chromosomes in Edessa irrorata (Hemiptera, Heteroptera). J Morph 69:587-604 (1941)

- Singh L, Purdom IF, Jones KW: Satellite DNA and evolution of sex chromosomes. Chromosoma 59:43-62 (1976).

Singh L, Purdom IF, Jones KW: Sex chromosomeassociated satellite DNA: evolution and conservation. Chromosoma 79:137-157 (1980).

- Singh L, Purdom IF, Jones KW: Conserved sexchromosome-associated nucleotide sequences in eukaryotes. Cold Spring Harb Symp Quant Biol 45:805-814 (1981).

- Siqueira S, Aguiar O, Souza MB, Lima AP, ReccoPimentel SM: Unusual intra-individual karyotypical variation and evidence of cryptic species in Amazonian populations of Pristimantis. Hereditas 146:141-151 (2009).

Slack HD: The association of non-homologous chromosomes in Corixidae (Hemiptera, Heteroptera). Proc R Soc Edinb Biol 58:192-212 (1938).

-Slizynsky BM: 'Ectopic' pairing and the distribution of heterochromatin in the X-chromosome of salivary gland nuclei of Drosophila melanogaster. Proc R Soc Edinb Biol 62:114119 (1945).

- Southern EM: Base sequence and evolution of guinea pig $\alpha$-satellite DNA. Nature 227:794798 (1970).

Taylor EH: Two new genera and a new family of tropical American frogs. Proc Biol Soc Wash 64:33-40 (1951).

Weisblum B: Fluorescent probes of chromosomal DNA structure: three classes of acridines. Cold Spring Harb Symp Quant Biol 38:441449 (1973).

Weisblum B, de Haseth PL: Quinacrine, a chromosome stain specific for deoxyadenylate-deoxythymidylate-rich regions in DNA. Proc Natl Acad Sci USA 69:629-632 (1972).

-Wiens JJ, Fetzner JW, Parkinson CL, Reeder TW: Hylid frog phylogeny and sampling strategies for speciose clades. Syst Biol 54:719-748 (2005).

-Yang F, Carter NP, Shi L, Ferguson-Smith MA: A comparative study of karyotypes of muntjacs by chromosome painting. Chromosoma 103: 642-652 (1995).

-Yang F, O’Brien PCM, Milne BS: A complete comparative map for the dog, red fox and human and its integration with canine genetic maps. Genome 62:189-202 (1999).

Yang F, Alkalaeva EZ, Perelman PL, Pardini AT, Harrison WR, et al: Reciprocal chromosome painting among human, aardvark, and elephant (superorder Afrotheria) reveals the likely eutherian ancestral karyotype. Proc Natl Acad Sci USA 100:1062-1066 (2003).
Chromosome Banding in Amphibia. XXXI. Centrolenidae and Allophrynidae
Cytogenet Genome Res 2014;142:268-285 DOI: $10.1159 / 000362216$ 